\title{
PERIPHERAL VASCULAR OBSTRUCTION IN RHEUMATOID ARTHRITIS AND ITS RELATIONSHIP TO OTHER VASCULAR LESIONS
}

BY

\author{
E. G. L. BYWATERS \\ From the Special Unit for Juvenile Rheumatism, Canadian Red Cross Memorial Hospital, Taplow, Maldenhead, Berks, \\ and the Department of Medicine, Postgraduate Medical School of London
}

(RECEIVED FOR PLBLICATION NOVEMBER 26, 1956)

Gangrene of the terminal portions of the limbs may be due to obstruction in the peripheral vessels, large or small, or it may be associated with cardiac failure as in rheumatic or ischaemic heart disease (Swan and Henderson, 1951), with ball valve thrombi, or with pulmonary disease (Boulet, Serre, Vedel, Vallat, and Mirouze, 1949; Hejtmancik and Bruce, 1953).

In a case of mitral stenosis and gangrene of the limbs and nose, in which I dissected the finger vessels and studied them in detail, no pathological changes were seen: the process had been thought to be one of low output and vasospasm. Obstruction peripherally may be due to primary changes in the blood, as in cryoglobulinaemia (Myerson and Stout, 1955), or to cold agglutination (Stats and Bullowa, 1943), but is more usually due to primary vessel disease, as in polyarteritis nodosa (Taylor and Jacoby, 1949), Buerger's disease, giant cell, or temporal arteritis (Chasnoff and Vorzimer, 1944), to multiple embolization, or to vasospasm, as in Raynaud's disease or crutch arteritis (Stammers, 1954). In scleroderma it seems possible that vessel changes precede the skin sclerosis.

Occasionally, however, an unusual type of peripheral arterial obstruction has been found which does not fit easily into any of the above categories (Whiteley and Wilson, 1952). It is the object of this study to describe such clinical and pathological changes occurring in the course of rheumatoid arthritis, and to discuss the relationship of these changes to those found in generalized lupus erythematosus, to the better-defined entities listed briefly above, and to the rarer ill-defined group of published cases not easily accommodated within these diagnostic pigeonholes.

Some years ago an account was published of six patients whose early clinical course resembled palindromic rheumatism, but who later showed clinical and radiological signs of rheumatoid arthritio and, in addition, some other curious features notably cutaneous nodules (Bywaters, 1949). One of these patients (Case 2) later died with gangrene of all four limbs. The present study describes the progress and terminal stages of this case, together with nine other examples of peripheral vascular obstruction (Table, opposite).

\section{Case Reports}

Case 1, a woman aged 28 (Case 2 of the previous publication), was admitted on May 14, 1946, with pain and swelling of the joints of the fingers and wrists which she had had for 3 years, with a pregnancy remission and postpartum relapse. Examination showed large olecranal and sacral nodules which histologically resembled those of rheumatoid arthritis. There was, in addition, mild erythema over the face, palmar reddening, and classical rheumatoid changes in the joints with radiological bone erosions and gross deformity. The erythrocyte sedimentation rate was raised $(20-50 \mathrm{~mm}$./hr Westergren), the colloidal gold test was strongly positive, and the white blood count was slightly diminished (4,000 per c.mm.). She showed pericarditis, cutaneous nodules on the terminal pads of the fingers and at the free edge of the nails, tendon nodules, transitory tenosynovitis, and other para-articular swellings.

During the next 2 years her condition remained much the same, although on occasions the white cell count fell to 3,000 per c.mm. with 33 per cent. polymorphs, which "together with a serositis, joint effusions, albuminuria, 
TABLE

PARTICULARS OF TEN CASES OF VASCULAR OBSTRUCTION

\begin{tabular}{|c|c|c|c|c|c|c|c|c|c|c|}
\hline $\begin{array}{l}\text { Case } \\
\text { No. }\end{array}$ & $\begin{array}{c}\text { Age at } \\
\text { Onset } \\
\text { (yrs) }\end{array}$ & Sex & $\begin{array}{c}\text { Duration of } \\
\text { Arthritis to } \\
\text { Death or } \\
\text { Follow-up (yrs) }\end{array}$ & $\begin{array}{c}\text { Differential } \\
\text { Agglutination } \\
\text { Test }\end{array}$ & “'L.E." & $\begin{array}{l}\text { Cryo- } \\
\text { globulin }\end{array}$ & $\begin{array}{l}X \text {-Ray } \\
\text { Erosions } \\
\text { of Joints }\end{array}$ & $\begin{array}{c}\text { Sub- } \\
\text { cutaneous } \\
\text { Nodules }\end{array}$ & $\begin{array}{l}\text { Cortisone } \\
\text { Treatment } \\
\text { preceding } \\
\text { Angiitis }\end{array}$ & $\begin{array}{l}\text { Vessels } \\
\text { Affected }\end{array}$ \\
\hline $1^{*}$ & 25 & $F$ & 6 (died) & $1: 64$ & - & - & + & + & 0 & $\begin{array}{l}\text { Four limbs } \\
\text { Viscera }\end{array}$ \\
\hline 2 & 29 & $\mathbf{M}$ & 12 (died) & $1: 512$ & 0 & 0 & + & + & + & $\begin{array}{l}\text { Four limbs } \\
\text { Viscera }\end{array}$ \\
\hline 3 & 35 & $F$ & 9 & $1: 64$ & $\begin{array}{l}\text { N.P.† } \\
\text { "positive", }\end{array}$ & 0 & + & + & 0 & $\begin{array}{l}\text { Fingers } \\
\text { (? kidney) }\end{array}$ \\
\hline 4 & 48 & $\mathbf{M}$ & 4 & $1: 32$ & 0 & 0 & + & + & $\therefore$ & Fingers \\
\hline 5 & 68 & $\mathbf{M}$ & 2 & $1: 64$ & 0 & - & + & $\because$ & 0 & Fingers \\
\hline 6 & 53 & $\mathbf{F}$ & 7 & $1: 32$ & 0 & 0 & + & + & $F$ & Fingers \\
\hline 7 & 45 & $\mathbf{M}$ & 13 & $1: 256$ & 0 & 0 & + & + & 0 & Fingers \\
\hline 8 & 41 & $\mathbf{F}$ & 13 & $1: 16$ & 0 & 0 & + & + & 0 & Fingers \\
\hline 9 & 23 & $\mathbf{F}$ & 8 & $1: 8$ & "positive" & - & 0 & $T$ & 0 & Fingers \\
\hline 10 & 38 & $\mathrm{~F}$ & 4 & $1: 128$ & $\begin{array}{c}\text { N.P.† } \\
\text { Positive }\end{array}$ & 0 & + & + & 0 & Fingers \\
\hline
\end{tabular}

*=Case 2 of previous publication (Bywaters, 1949).

$\dagger$ N.P. $=$ nucleophagocytosis.

and facial rash, suggested lupus erythematosus of the sub-acute disseminated or visceral type. No really characteristic rash or subsequent atrophy was, however, seen".

She survived just over a year from the time of the data recorded in the previous publication, with progression of the rheumatoid changes and ulnar deviation, hoarseness of the voice, Raynaud phenomena in her hands, indurated painful and pitting para-articular swellings on the volar surface below the elbow and above the wrist, nail-fold thromboses, and recurrent crops of cutaneous, tendinous, and subcutaneous nodules. During this period she showed recurrent and transient finger "blisters", intracutaneous nodules, numbering between twenty and thirty on the two hands at any one time. Occasional pains occurred in the abdomen, transitory in nature and ascribed by her to a cold on the spleen. The fingers became contracted, probably due to adhesions of tendons above the carpal ligament which was the site of a brawny inflammatory swelling.

Laboratory Findings.-The erythrocyte sedimentation rate remained between 20 and $30 \mathrm{~mm}$./ hr (Westergren), colloidal gold 5 units, white blood count 7,000 per c.mm. (October, 1948), differential agglutination test (D.A.T.) 1:64 (Original method, Rose, Ragan, Pearce, and Lipman, 1948.) There was no albuminuria. The chest $x$-ray was normal and the heart was normal clinically.

During this time she was able to do her house duties and look after her child, but with some difficulty. She was treated with aspirin, phenacetin, and codeine, with splints for night use. Local deep $x$-ray therapy failed to affect the disabling finger contractures and she was asked to come into hospital for an operation to free the tendons.

This operation was not performed, however, because her right index finger in the meantime (February, 1949) had become mottled and cyanotic following extensive subcuticular blisters developing at the site of a cutaneous nodule. These ulcerated, and were treated with antibiotics before and during her fifth and final hospital admission (from March 16, 1949). The heart began to enlarge clinically and radiologically, with a mitral systolic murmur and concordant left ventricular preponderance. Dr. Paul Wood thought there was "a serious degree of cardiac involvement". The blood pressure had risen by this time to $210 / 135$ (February 16, 1949), and stayed at this level 215/135 (March 16, 1949); 15 months previously it had been only 120/80. Albumen appeared in the urine in large amounts after admission.

Despite antibiotics, the right index finger progressed to gangrene. The ulcerated nodules, e.g. on the left foot and on the right elbow, had healed up, but the nodule on the right elbow was still ulcerating and discharging. The arthritis now appeared to be quiescent. In view of this evidence of peripheral and possibly renal vascular disease, a muscle biopsy was done with the diagnosis of polyarteritis nodosa in mind, but showed no abnormality.

Laboratory Findings. - White blood count during this period within normal limits $(9,000 \mathrm{c} . \mathrm{mm}$.; 71 per cent polymorphs); erythrocyte sedimentation rate $60 \mathrm{~mm}$./hr., with plasma albumin $3 \cdot 1 \mathrm{~g}$. per cent., globulin $3 \cdot 3 \mathrm{~g}$. per cent.; colloidal gold $0 ; 17$-ketosteroids $9.9 \mathrm{mg} . / 24 \mathrm{hrs}$. 
Electrocardigram showed a prolonged QTc and changes consistent with pericarditis and left ventricular predominance. Bone-marrow films showed increased granulocyte activity.

Scaly red macules now appeared on the skin of the elbows which Dr. Stephen Gold thought were compatible with those of Libman Sachs's disease.

Gangrene then appeared in the right foot and in the left hand and the left toes and gradually spread to involve the whole of the hands as far as the wrists (Fig. 1).
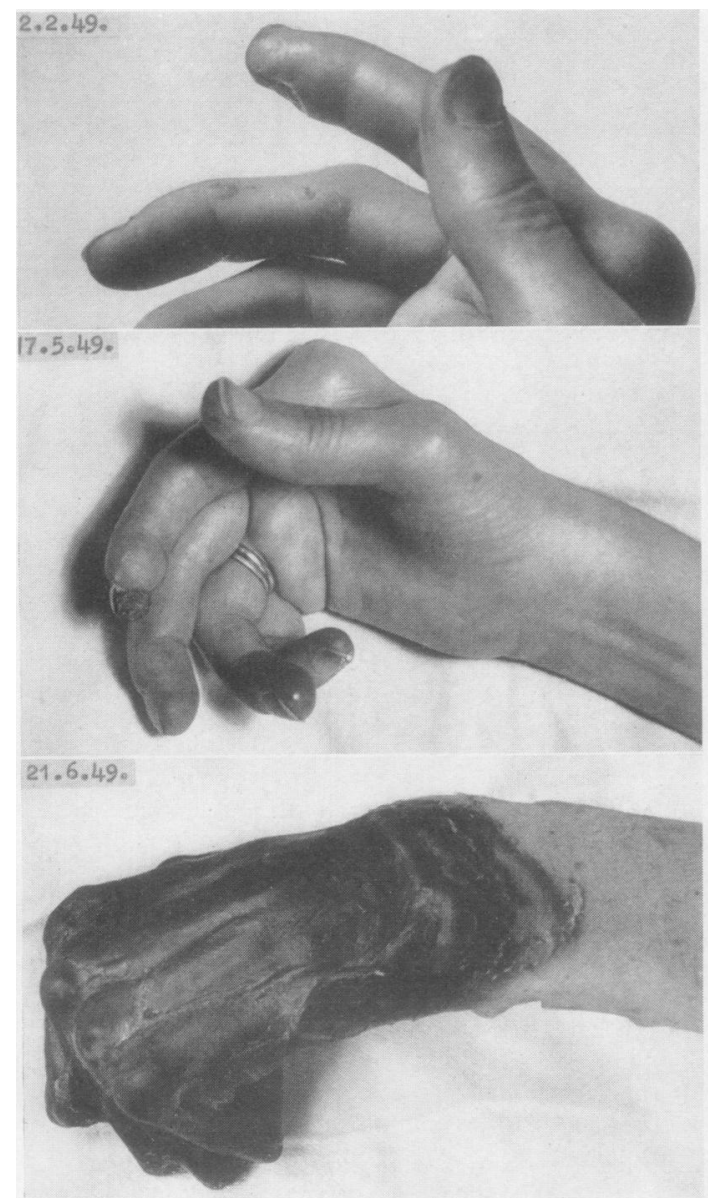

Fig. 1.-Case 1, nodule undergoing ulceration in index finger and progressing to gangrene (May, 1949), with ischaemia also of fourth and fifth digits. In June, 1949, both hands showed gangrene as far as the wrists.

Arteriography of the right leg showed narrowing of the anterior tibial vessels at the junction of the upper and middle thirds. Heart failure supervened with oedema, increased jugular venous pressure, and enlargement of liver and spleen. The patient developed terminal twitchings on the left side and died in coma on June 15, 1949,
6 years after the onset of the rheumatoid arthritis.

A post mortem examination by Dr. Lennox showed adhesions in pleurae, pericardium, and upper peritoneum, ulcers of jejunum and colon, and small necroses in the pancreas. The heart weighed $440 \mathrm{~g}$. with left ventricular hypertrophy and thickening of the chordae tendiniae. There were pericardial adhesions and shelf-like vegetations on the contact margins of the mitral valve (Fig. 2) "not of the Libman-Sachs type but more resembling marantic vegetations".

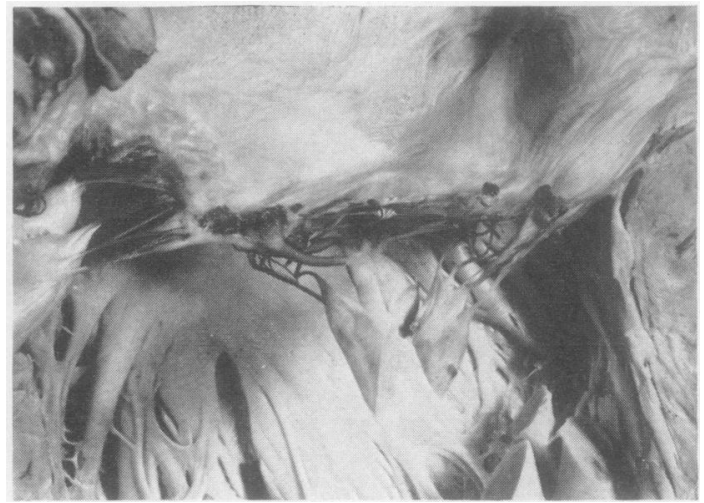

Fig. 2.-Case 1, marantic vegetations on mitral valve.

The kidneys weighed $23 \mathrm{C}$ and $210 \mathrm{~g}$. with swollencō cortex and subcapsular haemorrhage (Fig. 3).

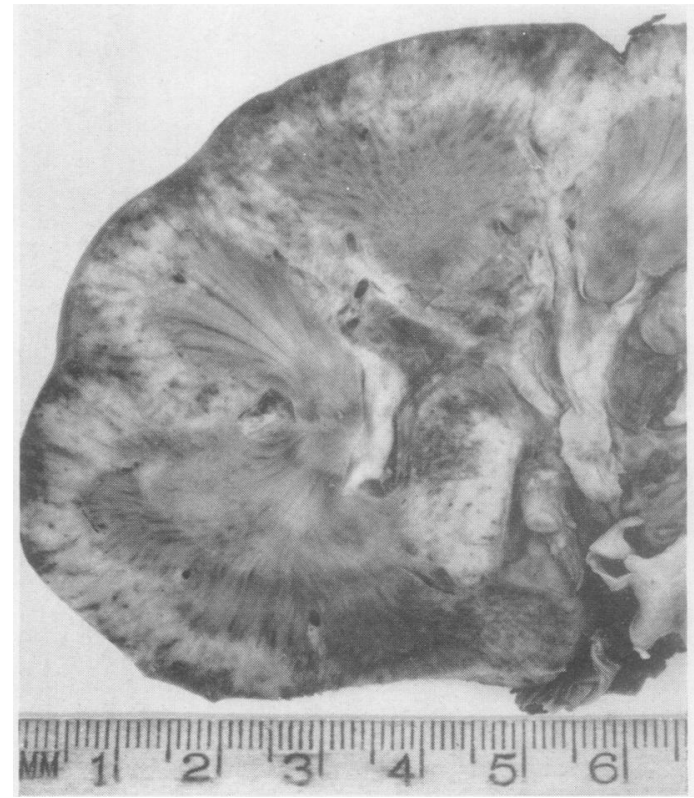

Fig. 3.-Case 1, kidneys, showing mottling of cortex. 
The spleen was slightly enlarged.

An $x$-ray of the leg was taken after mercurial cream injection (Prof. J. H. Dible). The femoral and popliteal vessels were thick-walled and small in calibre but patent. The posterior tibial artery was thick-walled and then narrowed rapidly to a pin-point at $15 \mathrm{~cm}$. above the ankle; $4.5 \mathrm{~cm}$. lower down it became abruptly re-established and continued. The fibular artery was thick and prominent throughout its course, with a concentrically narrowed lumen, especially in the proximal $10 \mathrm{~mm}$., which had not become injected. The anterior tibial artery was patent throughout, with a moderate degree of concentric narrowing of the lumen. The smaller arteries were greatly reduced in frequency in the distal quarter of the leg and all tailed off at the level of the gangrene.

Microscopically there was a widespread obliterative endarteritis. Small arteries were rarely affected, the maximal incidence of this change being seen in the medium-sized muscular arteries of the pancreas (Fig. 4), gut, adrenal, kidney (Fig. 5, overleaf), muscle (Fig. 6, overleaf), tendon, skin, and particularly of the limbs.

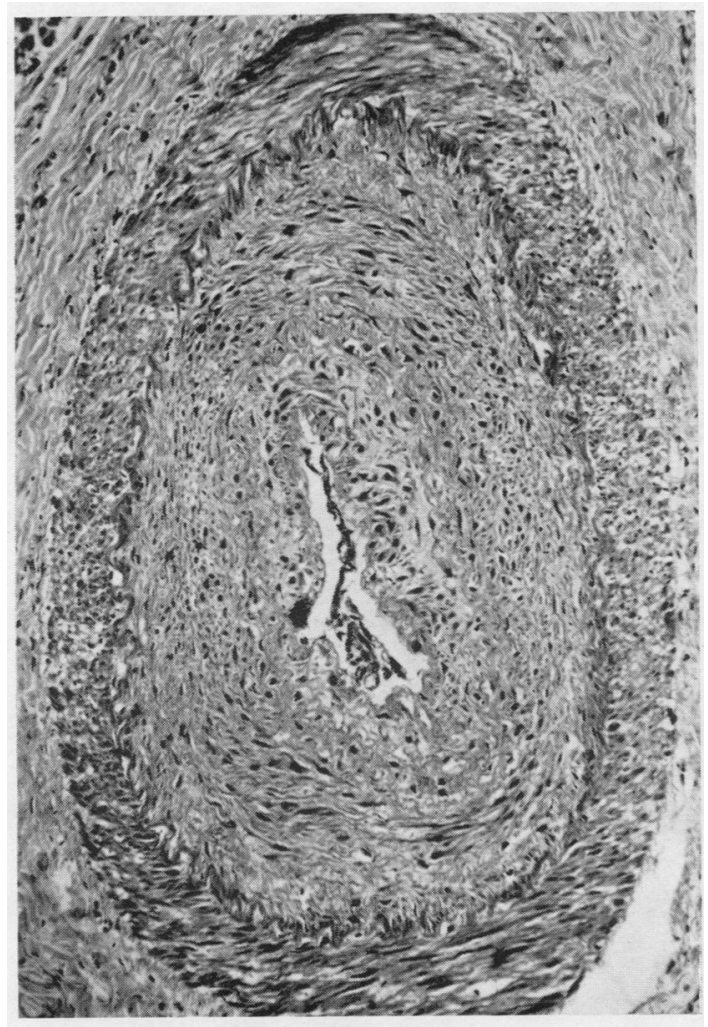

Fig. 4.-Case 1, artery from pancreas, showing intact elastica and intima with several layers of obliterative change. H and E. $\times 140$.
There was concentric thickening of the intima by loose, sometimes mucoid, fibrous tissue, with occasional total occlusion by eosinophil fibrin-like material (Fig. 7a, $b$, overleaf), sometimes with local haemosiderin deposits on this final plug, sometimes with recanalization (Fig. 8, overleaf).

The internal elastica was usually whole, but in some areas of a few vessels it had become thinned or had disappeared with some nuclear debris extending slightly into the media (Fig. 9, overleaf).

Occluded vessels showed some medial capillarization but seldom the elastica reduplication seen in non-occluded vessels with intimal thickening and thought to be an added response (to hypertension) as in Fig. 10 (overleaf).

There were no giant cells. The accompanying veins were generally normal, except that there was recent clot in the lower limb extending up as far as the femoral vein from the gangrenous area. Very rarely, there was slight intimal thickening of a vein.

Besides these obliterative arterial changes, there was some fibrinoid necrosis in the arterioles of the gut, pancreas, and kidney, which in the renal pelvis progressed to changes resembling polyarteritis nodosa (Fig. 11, overleaf).

One pulmonary artery showed segmental fibrinoid change in its wall and fibrin incorporated in the intima.

The glomeruli showed fibrinoid necrosis of part of the loops (Fig. 12, overleaf).

The heart showed verrucous endocarditis and old pericarditis.

The spleen showed periarteriolar fibrosis rather beyond normal limits for this age.

The olecranal nodule showed necrotic material lying in avascular collagen, a healed stage of a large, typically rheumatoid nodule. Synovial membrane from the knee (which had previously shown effusions) was normal, but section of the metatarsophalangeal joints showed destruction of cartilage and healed bone erosions in an advanced state of autolysis.

In the previous publication (Bywaters, 1949), the discussion of this case, which was diagnosed as rheumatoid arthritis, was concerned with lupus erythematosus; it was concluded that there were grounds for supposing that this case might be one of acute lupus erythematosus, but that the course and the joint changes were characteristic of rheumatoid arthritis, as was also the nodule. The later course gave no reason to change this opinion. No examination for L.E. cells was made. The fibrinoid necrosis, the glomerular changes, and the periarteritis-like changes in the renal pelvis were possibly the result of hypertension, but the obliterative endarteritis was more probably the cause rather than the result of the hypertension. 


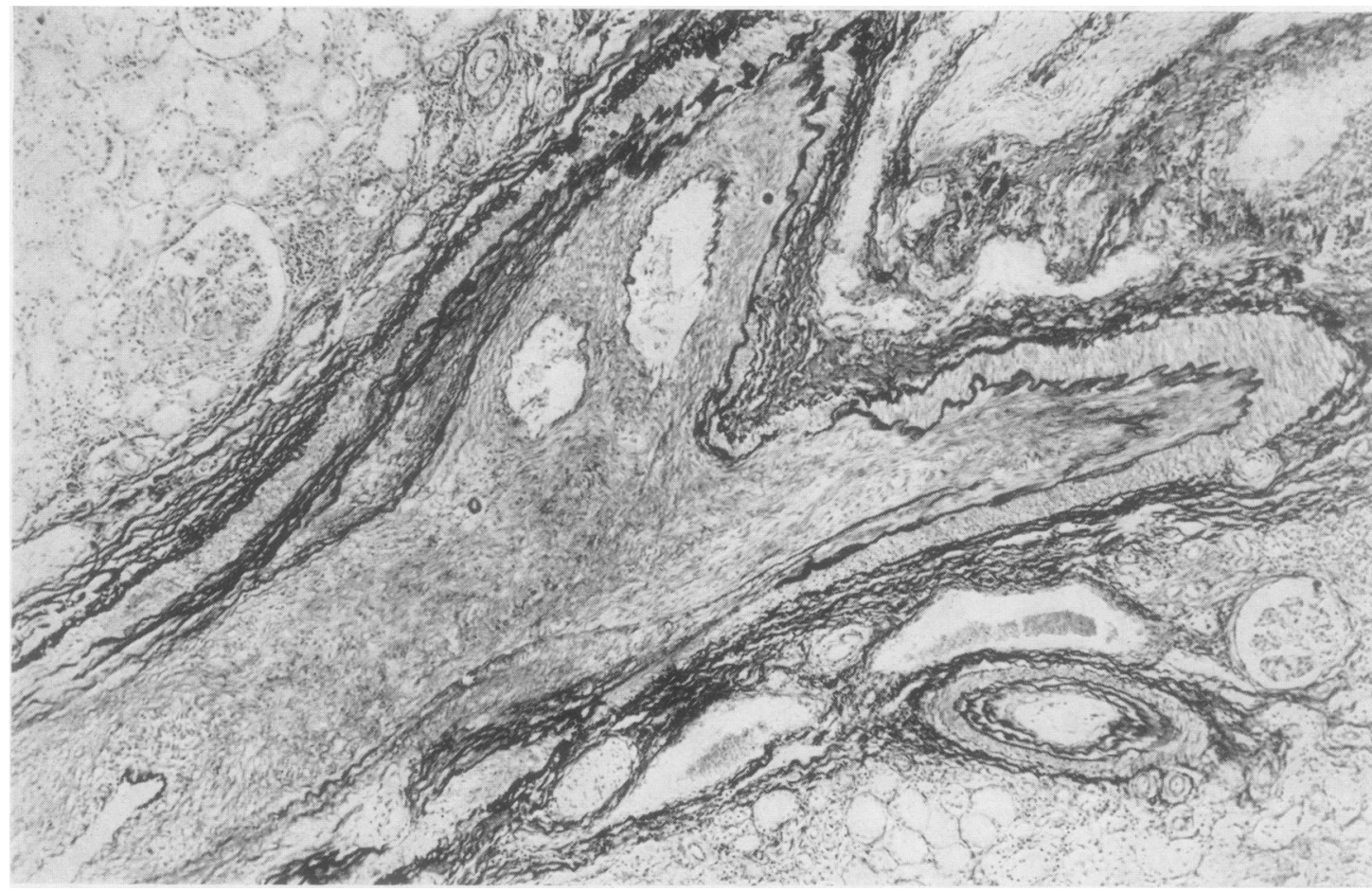

Fig. 5.-Case 1, renal artery, showing obliteration of lumen. Van Gieson and elastin. $\times 60$.

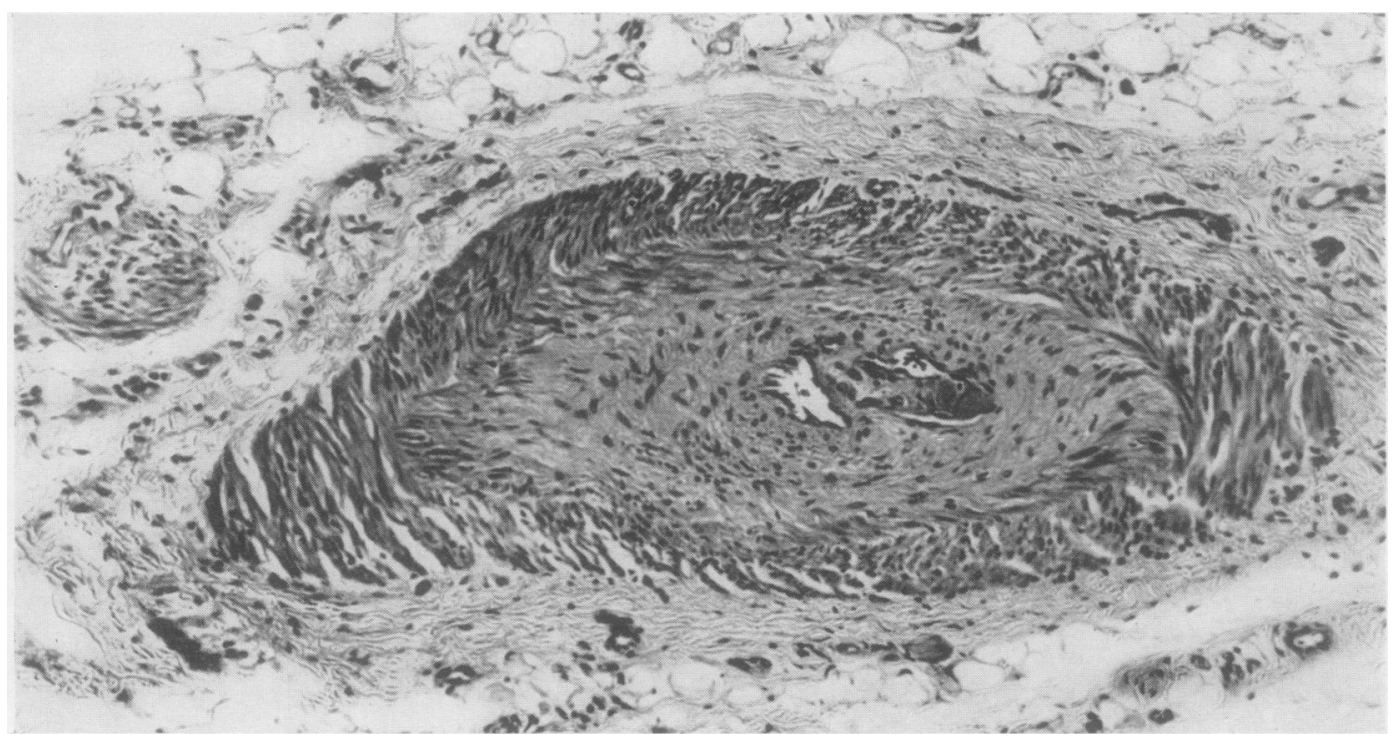

Fig. 6.-Case 1, artery from voluntary muscle, showing obliteration of lumen by proliferating intima. $\mathrm{H}$ and $\mathrm{E} . \quad \times 105$. 


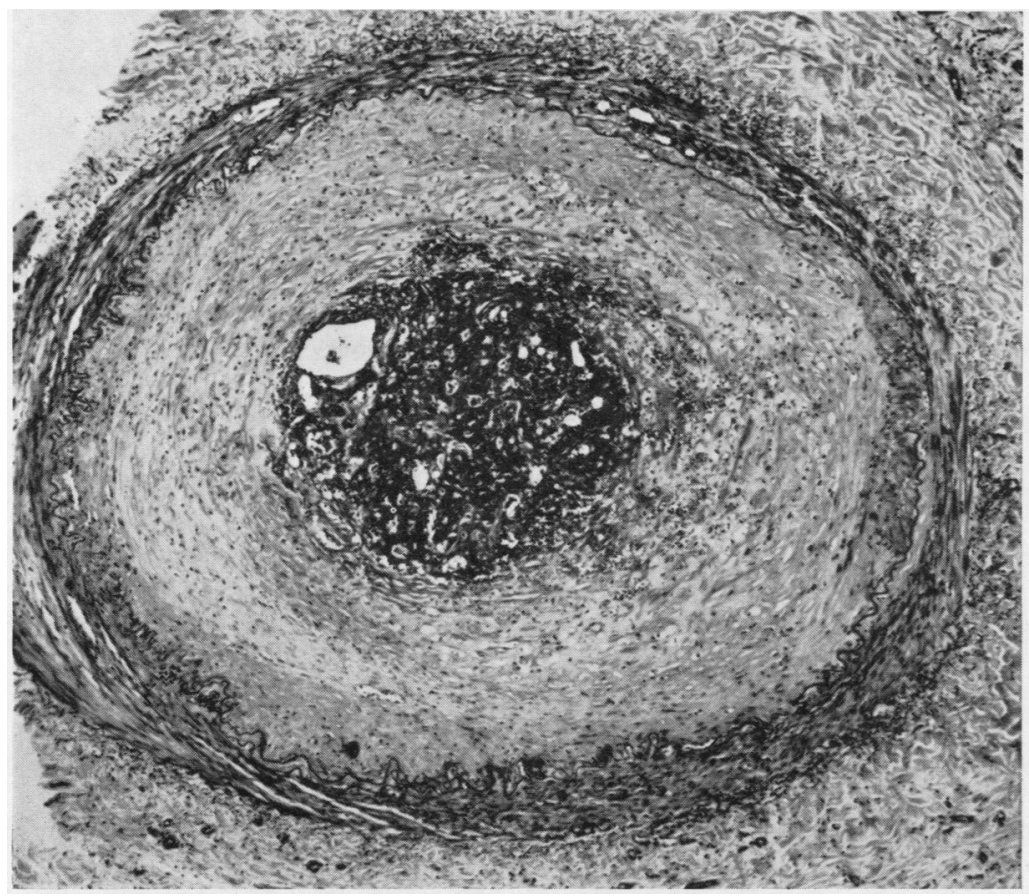

Fig. 7(a).-Case 1, fibular artery, showing intimal proliferation and thrombotic occlusion centrally with recanalization. $\mathrm{H}$ and $\mathrm{E}$. $\times 70$.

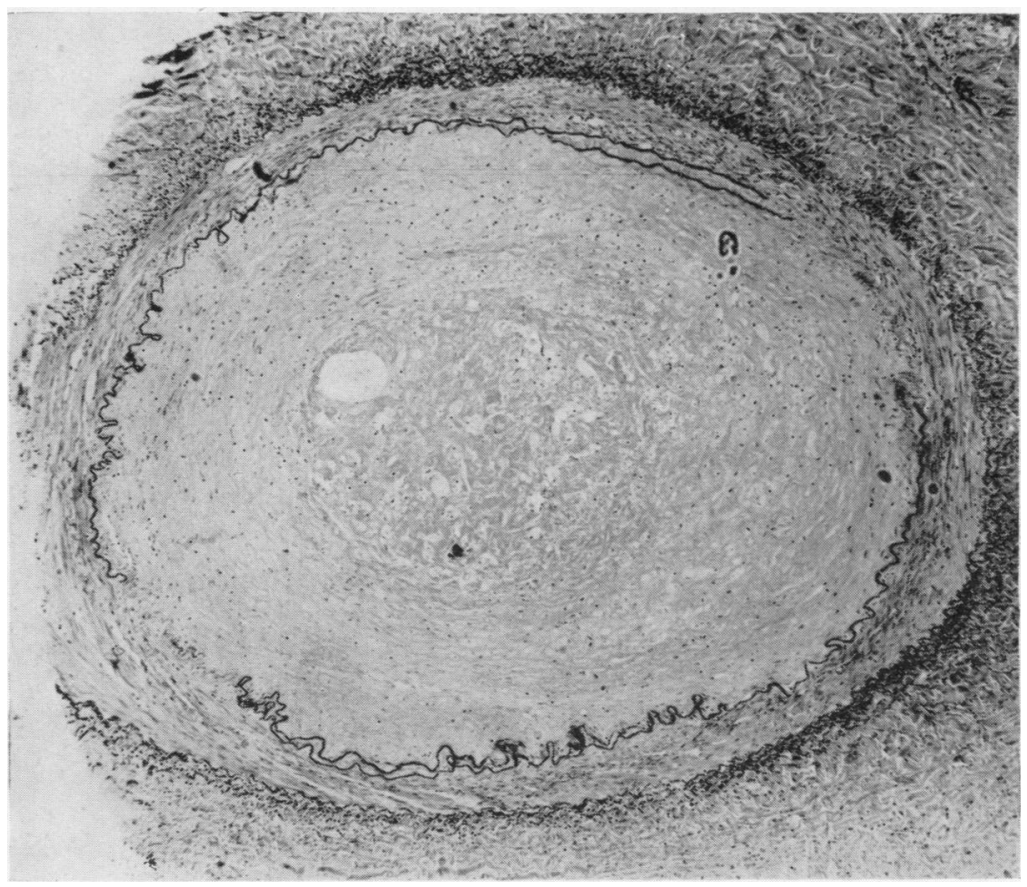

Fig. 7(b).-Case 1, same stained for elastin showing duplication and interruption of elastic lamina. 


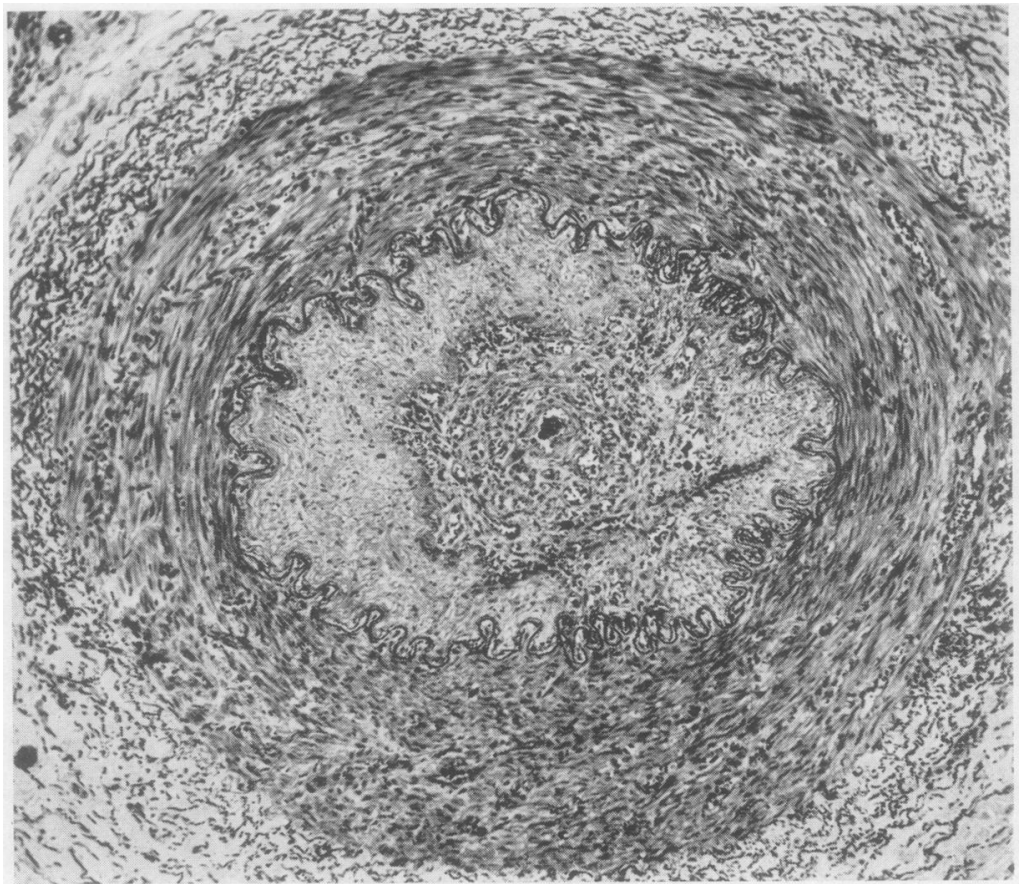

Fig. 8.-Case 1, dorsalis pedis artery, showing intimal proliferation, central thrombosis with recanalization, intact elastica, and some capillary invasion of media. $\mathrm{H}$ and $\mathrm{E} . \quad \times 70$.

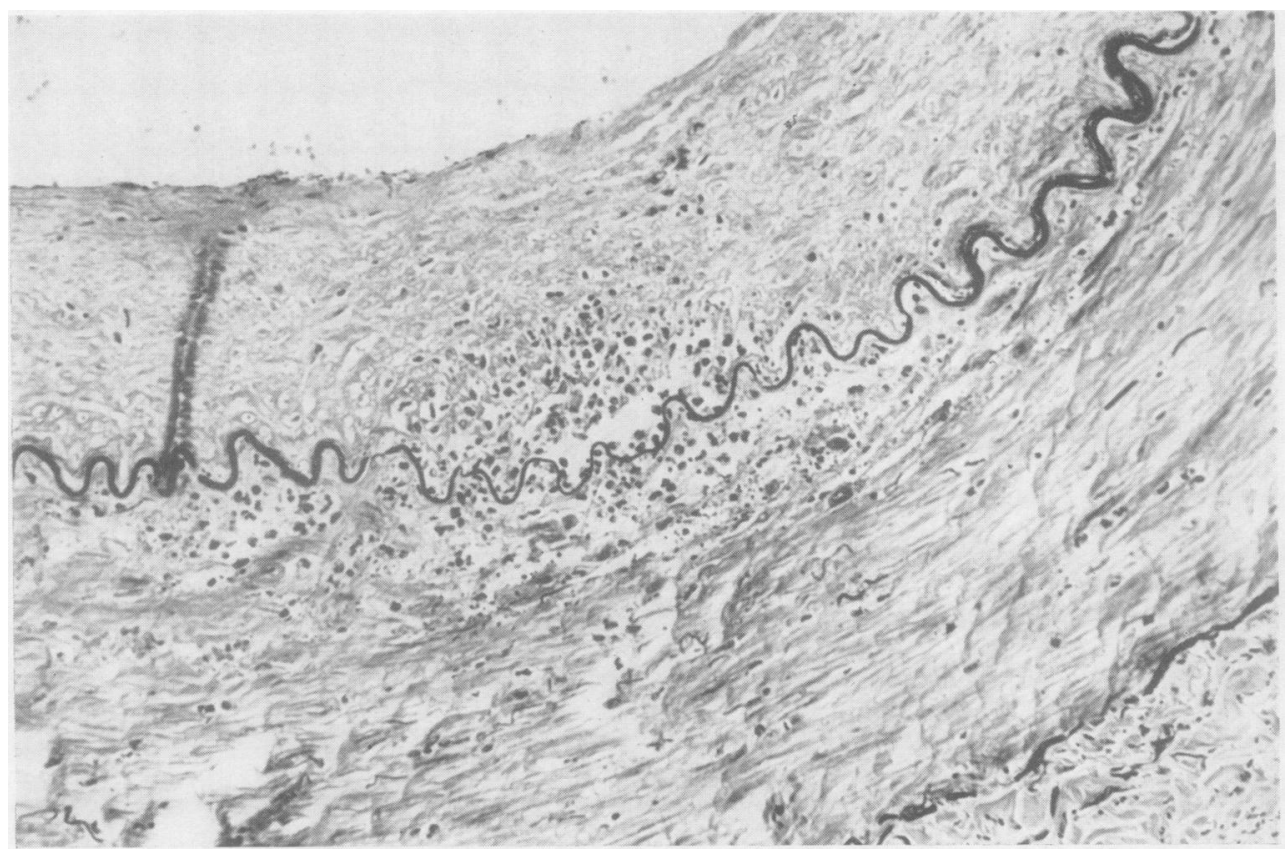

Fig. 9.- Case 1, artery from tendon sheath, showing thinning of internal elastica and some necrotic nuclear debris on each side of this. The intima is thickened but the lumen is not obliterated. Van Gieson and elastin. $\times 200$. 


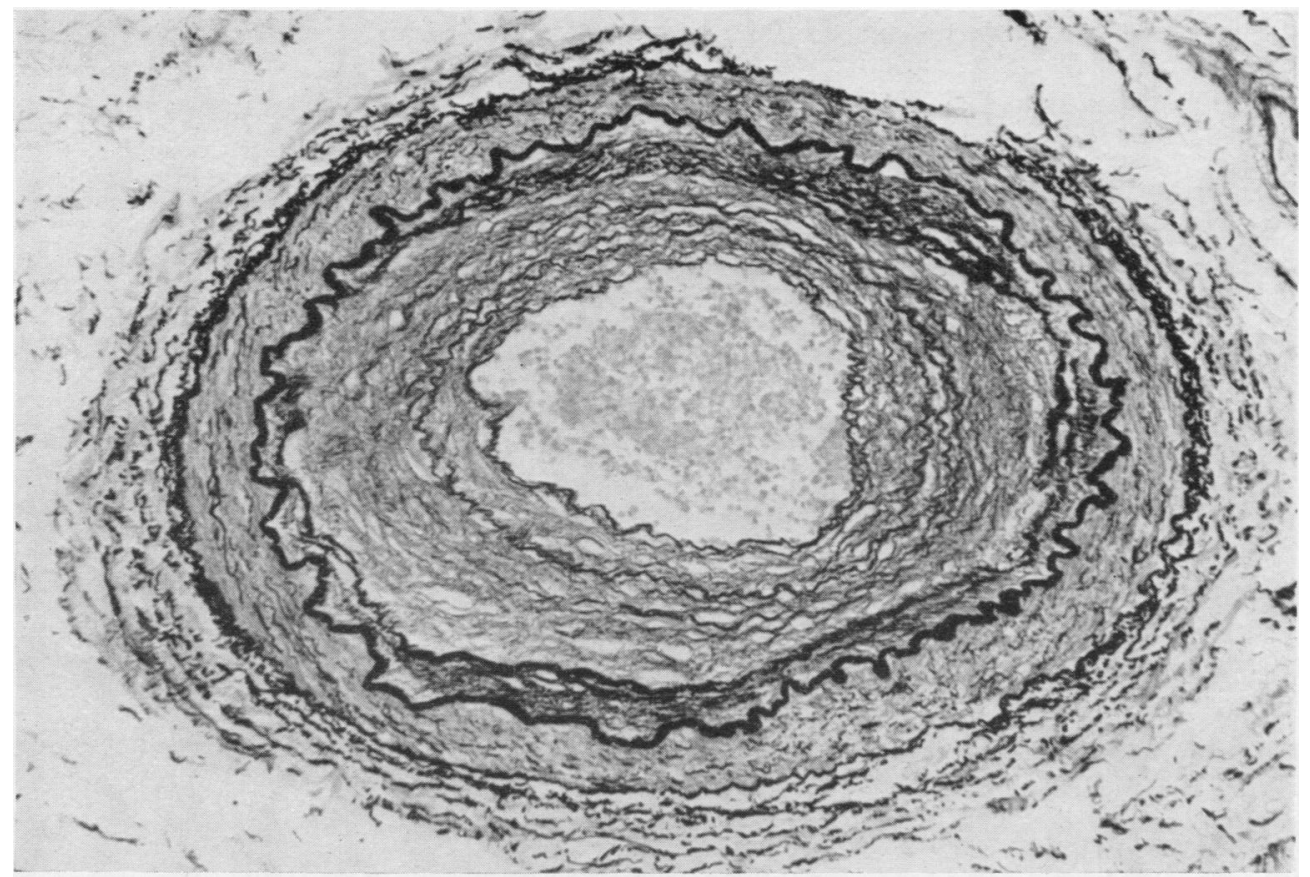

Fig. 10.-Case 1, artery from gut, showing secondary results of hypertension with new formation of elastin fibres in intima. Elastin

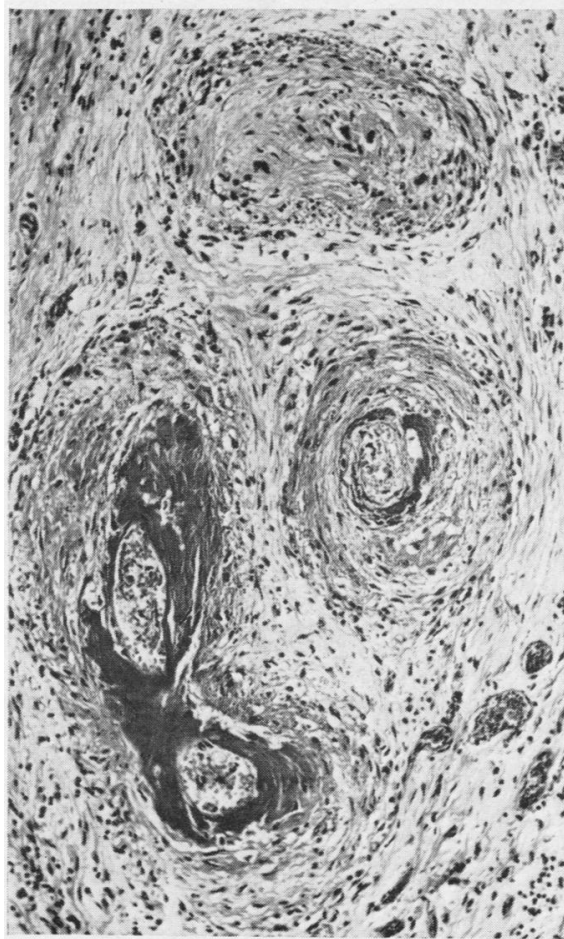

Fig. 11.-Case 1, arteries from renal pelvis, showing fibrinoid and obliterative endarteritis and periarteritis. $\mathrm{H}$ and $\mathrm{E} . \quad \times 135$.

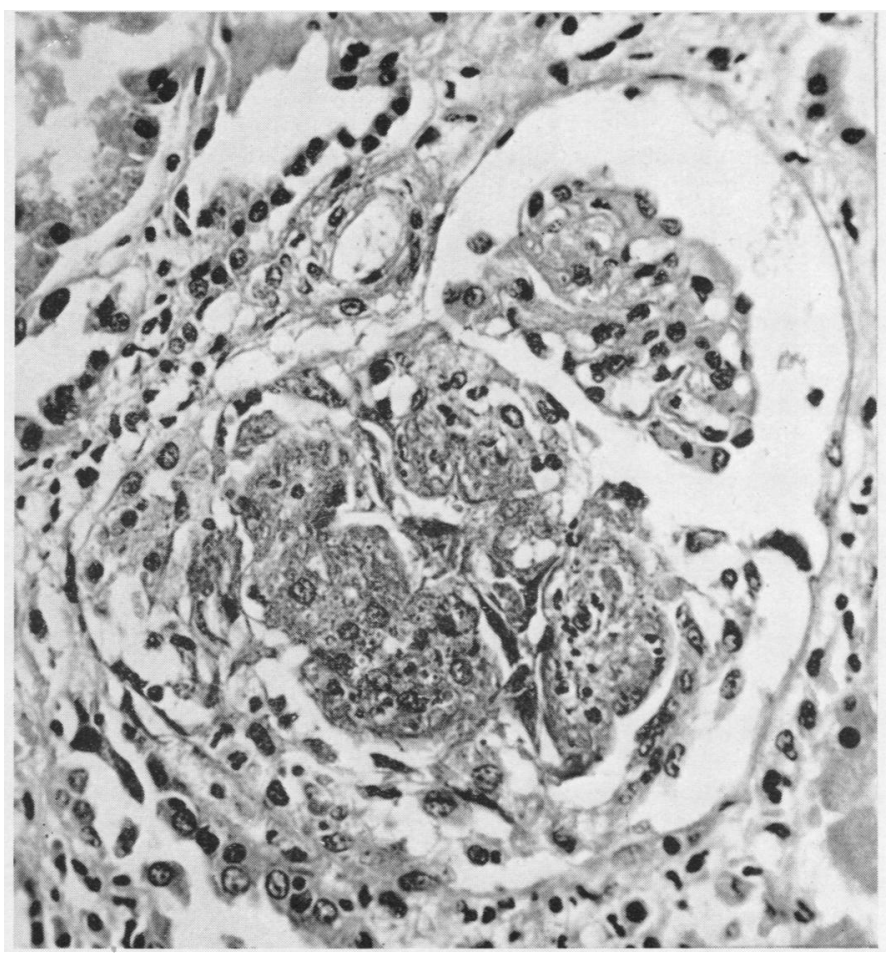

nephritis. $\mathrm{H}$ and $\mathrm{E}$. $\times 380$.

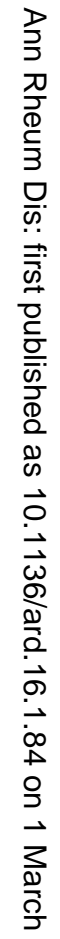

$\overrightarrow{0}$

ᄋ.า

言.

$\stackrel{一}{\rightleftharpoons}$

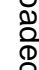

$\stackrel{\mathbb{2}}{2}$

읔

票

음

3

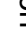

응

ก

N

ก

$\omega$

产

음

$\stackrel{9}{9}$

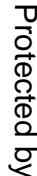


Case 2, a man aged 37, was first admitted in March, 1952, with a history of rheumatoid arthritis which had started 9 years previously while he was a prisoner-of-war in Singapore. There was rapid involvement of hands, wrists, shoulders, knees, feet, and hips, which after repatriation was treated with physiotherapy, gold, and $x$ rays during twelve admissions to other hospitals.

Arthroplasty was performed for a fractured neck of the femur, and he was given ACTH and phenylbutazone.

Albuminuria appeared for the first time 2 years later (January, 1954) and rapidly increased, so that between 4 and $15 \mathrm{~g}$. were lost per $24 \mathrm{hrs}$.

Laboratory Findings.-Blood urea and intravenous pyelogram normal; Congo red test positive; blood pressure 140/90; erythrocyte sedimentation rate 42-124 $\mathrm{mm} . / \mathrm{hr}$ (Westergren); Wassermann reaction and Kahn test negative; L.E. cells not found; D.A.T. 1:512. There were advanced changes characteristic of rheumatoid arthritis in all joints with gross radiological destruction and a rheumatoid nodule on the elbow.

Improvement followed ACTH gel and cortisone, so that on discharge he was able to walk.

However, he was re-admitted 3 weeks later with dyspnoea, chest pains, gross oedema of the legs, and pain in the toes. The blood pressure was 120/90, and the jugular venous pressure not increased with bilateral pleural effusions. Besides the subcutaneous nodules on the elbows (biopsied and typical of rheumatoid arthritis), there were multiple nail-fold capillary thromboses and necroses (confirmed by capillary microscopy), intracutaneous nodules on both hands and elbows similar to those in Case 1, starting as raised indurated red areas and later developing a brown central scar, digital pulp nodules on the fingers, and pigmented scars at the free edges of the nails. The pain in the toes was due to subcuticular gangrene and a small patch of gangrene was seen on the index finger.

Laboratory Findings.-Erythrocyte sedimentation rate $120 \mathrm{~mm}$./hr. L.E. cells and L.E. cell factor still absent. Direct Coombs test negative. Cold agglutinins and cryoglobulins absent. Blood urea $35 \mathrm{mg}$. per cent. Differential agglutination test 1:512. Albumin 1.2, globulin $4 \cdot 8 \mathrm{~g}$. per cent. White blood count 17,000 per c.mm. Blood culture sterile. No casts or cells in urine deposit. Protein output $10 \mathrm{~g} . / 24 \mathrm{hrs}$.

Treatment with cortisone $100 \mathrm{mg}$. per day, antibiotics, and mercurials was ineffective and, although all the peripheral pulses remained palpable, the gangrene progressed and the patient died 3 months after the final admission, which was 3 years after his first admission.

A post mortem examination showed severe changes of rheumatoid arthritis in most joints and tendon sheaths. The olecranal nodules showed central necrosis, but the palisade layer of cells had practically disappeared. There was gross amyloidosis of the spleen, kidney, and adrenals, and lesser changes in the vessels of other viscera.

The endothelium at the base of the mitral valve showed slight thickening (Fig. 13) due to proliferation of endothelial cells (indicated by reticulin network) (Fig. 14).

Moderate-sized coronary arteries were partially

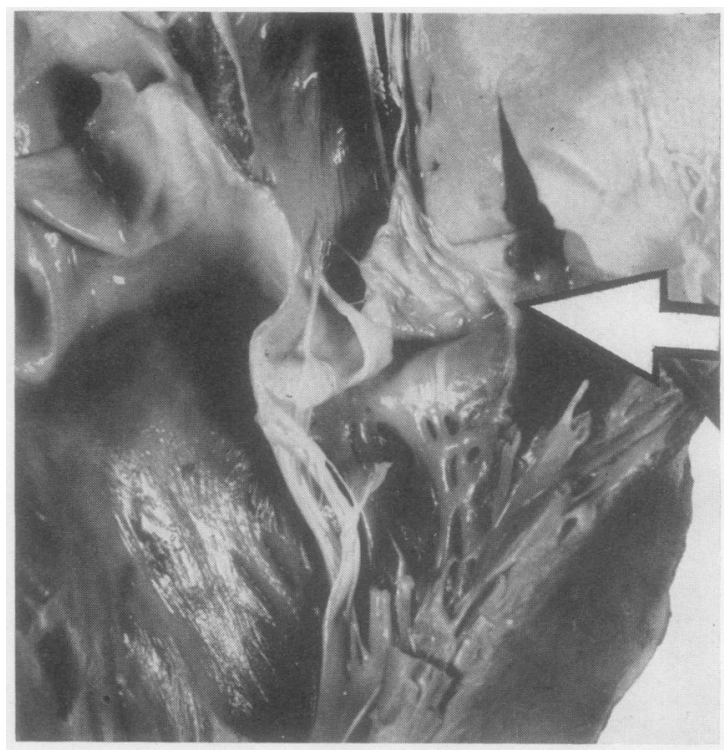

Fig. 13.-Case 2, mitral valve, showing infiltration, and endothelia thickening in pocket below valve leaflet (Arrow).

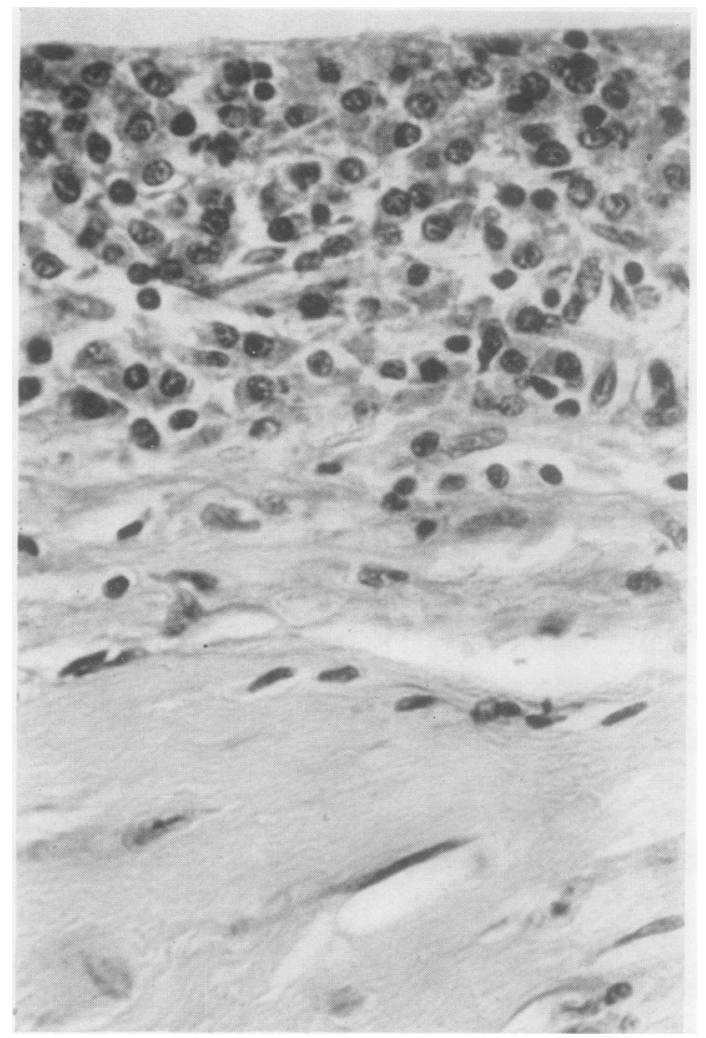

Fig. 14.-Case 2, mural endocardium, showing endothelial cell proliferation. $\mathrm{H}$ and $\mathrm{E}$. $\times \mathbf{5 0 0}$. 
occluded by intimal proliferation, which was also seen places of media and elastica and with an adventitial elsewhere (Fig. 15), with partial destruction in some cellular reaction (Fig. 16).

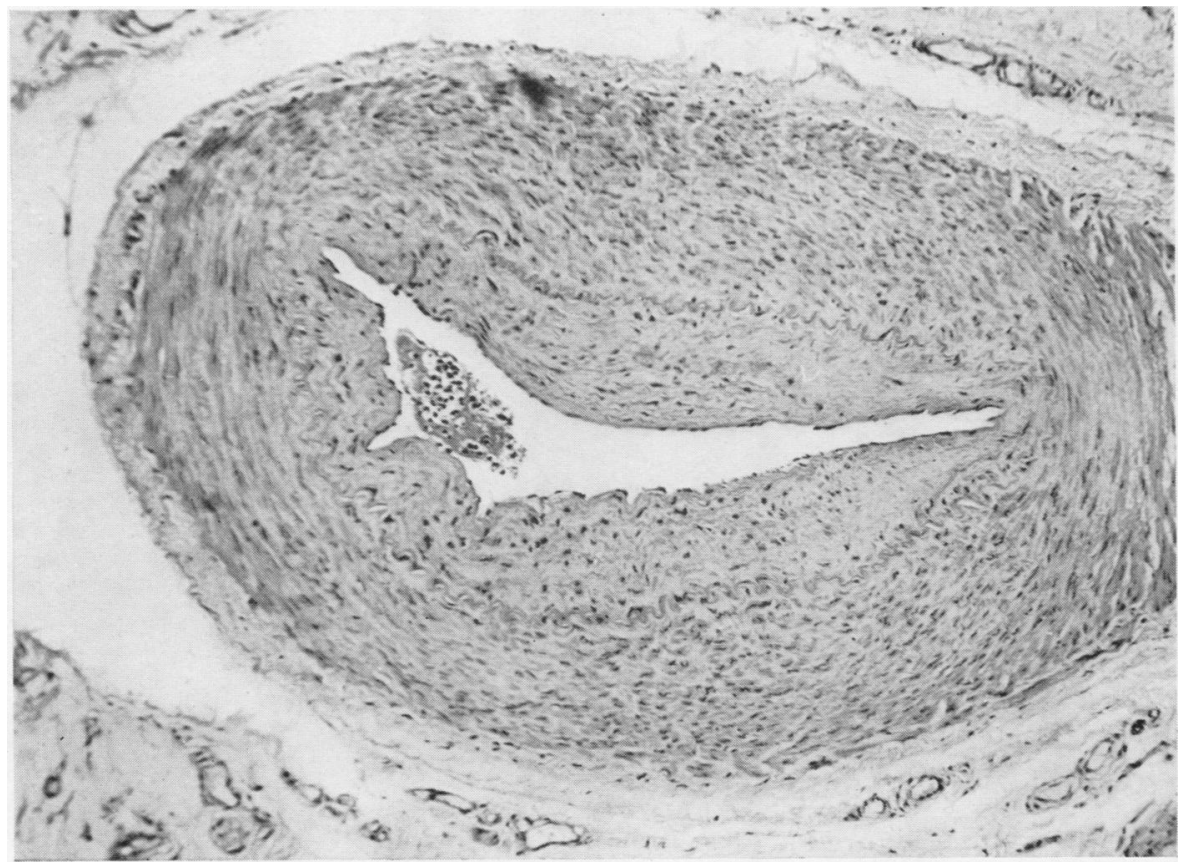

Fig. 15. - Case 2, artery from left third digit, showing early and partial intimal thickening. $\mathrm{H}$ and $\mathrm{E} . \quad \times 500$.

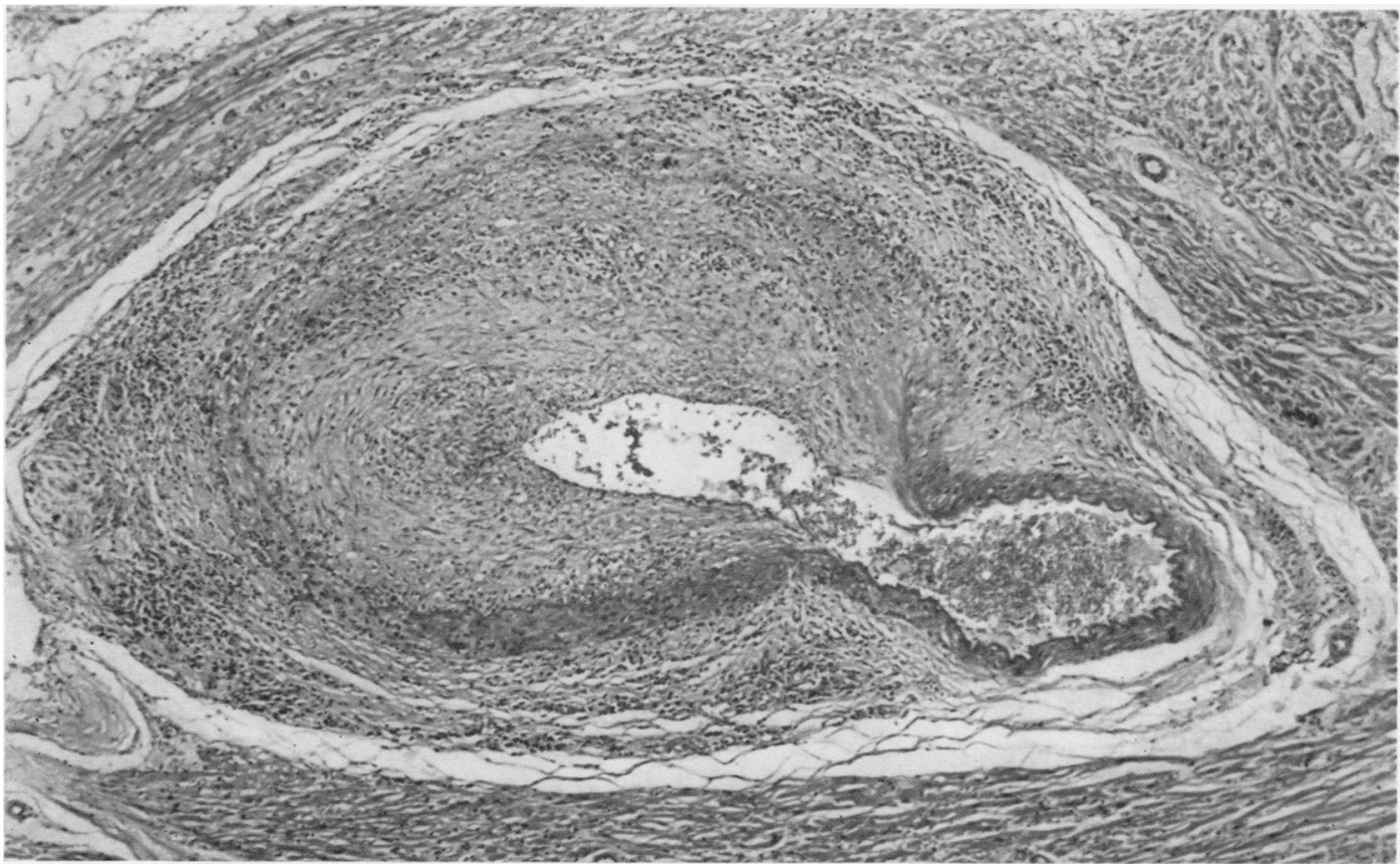

Fig. 16.-Case 2, coronary artery, showing destruction of vessel wall, intimal proliferation, and panarteritis. $\quad$ H and E. $\quad \times 65$. 


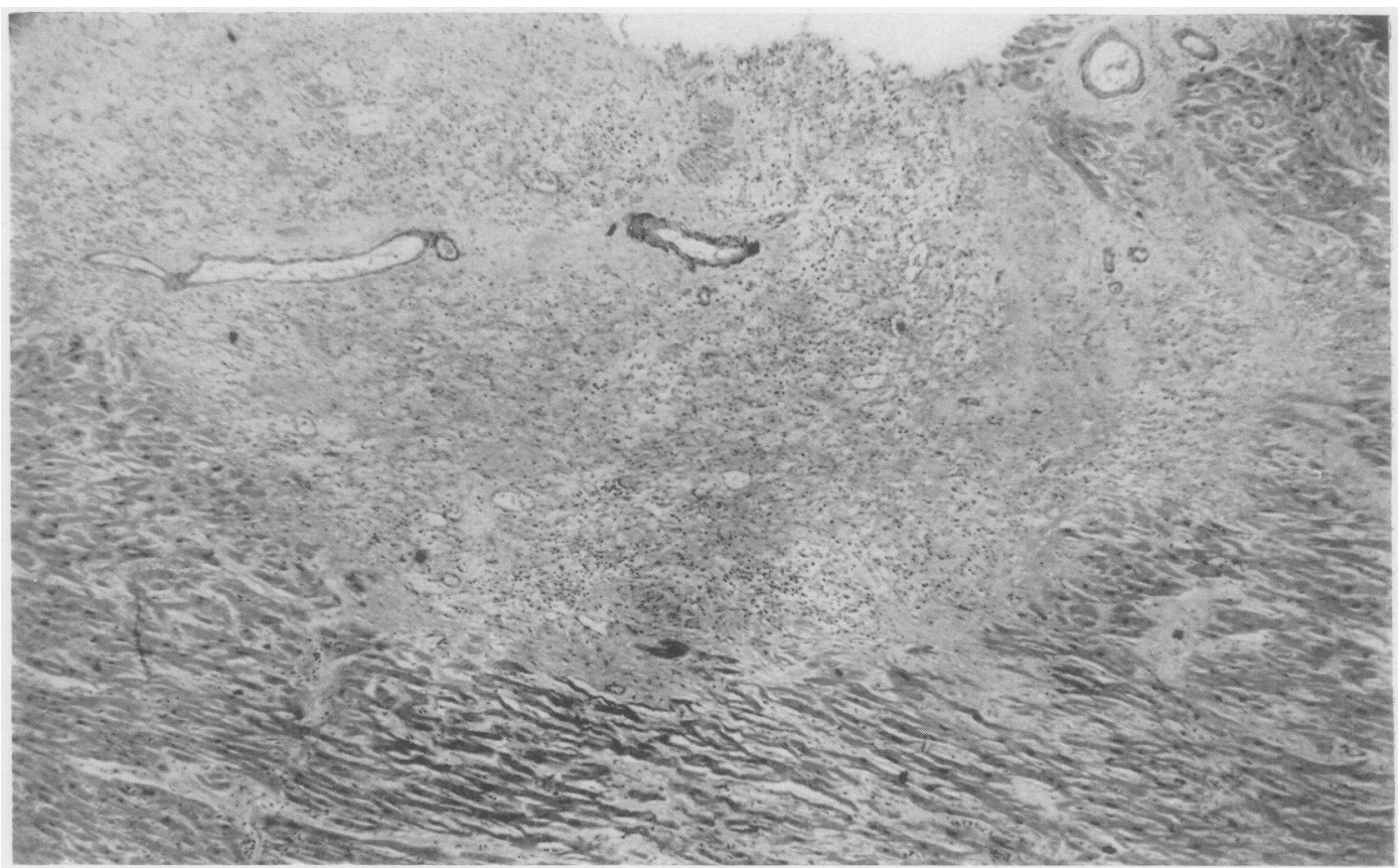

Fig. 17.-Case 2, myocardium, showing ischaemic scars, $H$ and E. $\times 40$.

These caused small necrotic areas (Fig. 17), widely distributed and visible macroscopically (Fig. 18).

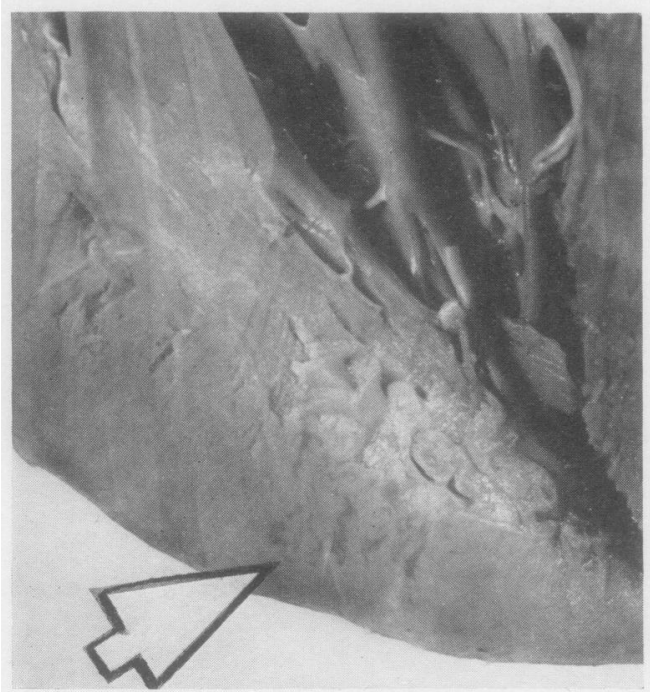

Fig. 18.-Case 2, myocardium of left ventricle, showing patchy ischaemic necrosis (Arrow).

The left pectoral muscle showed ischaemic necrosis of its distal portion, visible macroscopically.

Arteries in the spleen, peri-adrenal fat, gut, and limbs als o showed partial or complete occlusion due to concentric intimal proliferation, often without adventitial reaction as in the left third digital artery (Fig. 19).

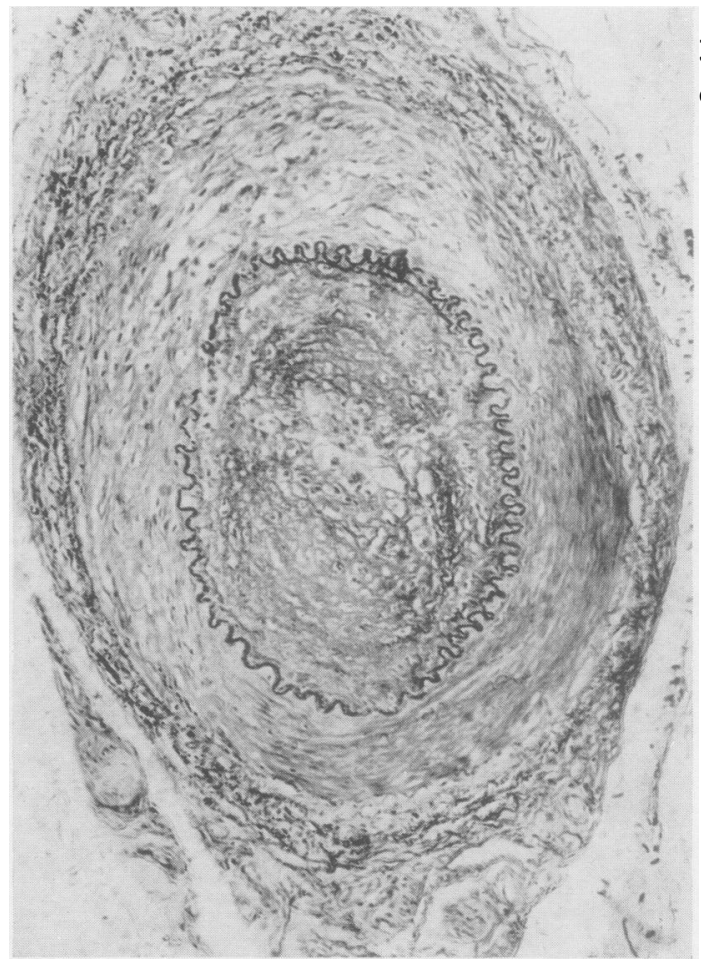

Fig. 19.-Case 2, left third digital artery, showing intimal proliferation and intact elastica. Elastin. $\times 90$. 
Sometimes the arteries showed no lesions of media or elastica (Fig. 20), and sometimes they showed both these changes in some degree (Fig. 21).

These two cases are to be classified as malignant rheumatoid arthritis with obliterative endarteritis and gangrene. The intracutaneous nodules with a brown central necrotic patch and scar, occurring on hands, elbows, digital pulps, nail-folds, and at the free corner margins of the nails, seem to be the early expression of this vascular change.

However, these lesions do not always lead to gangrene; eight other patients with rheumatoid arthritis (Cases 3-10) have been observed, for variable periods up to 6 years, with similar lesions but without gangrene.

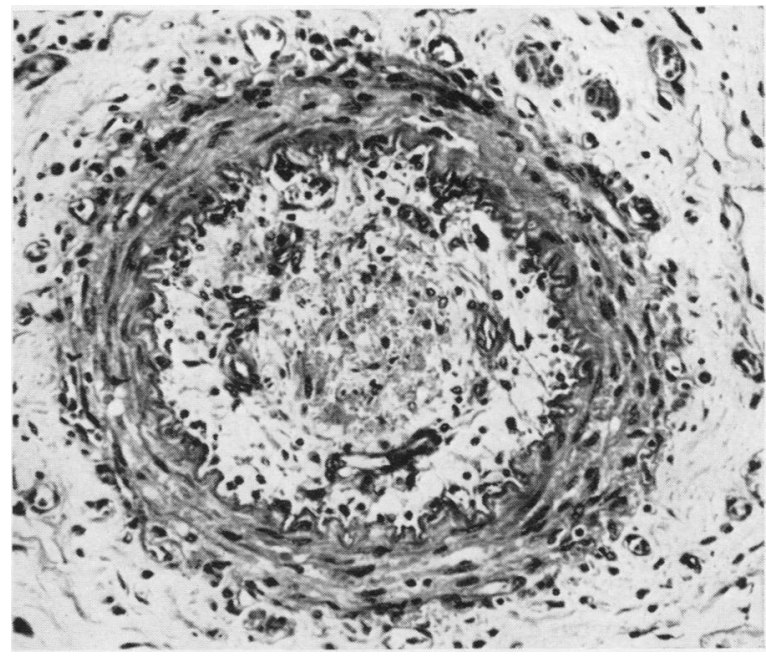

Fig. 20.-Case 2, artery from gut, showing intimal proliferation in two stages with occlusion. $H$ and $E . \times 210$.

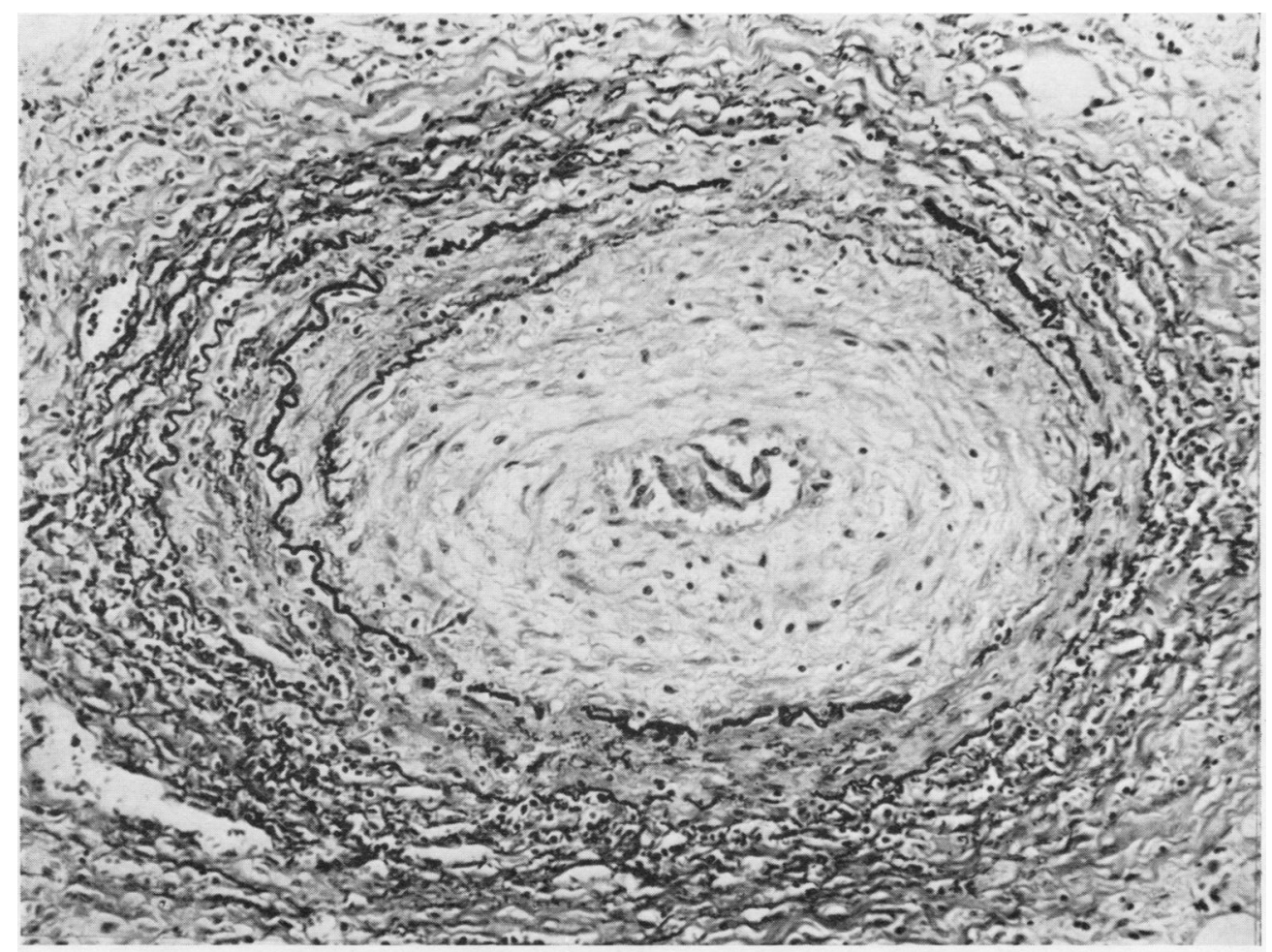

Fig. 21.-Case 2, artery in peri-renal fat, showing lesions of elastica, medial scarring, and adventitial reaction. Van Gieson and elastin. $\times 200$. 
Case 3, a woman aged 39, was first admitted to the Canadian Red Cross Memorial Hospital in October, 1951, with typical symmetrical rheumatoid arthritis, which had started 5 years before at the age of 34 after a 2 months' miscarriage. She had later had a brief pregnancy remission, and, at the age of 37, left-sided colic led to the discovery of renal calculi and a non-functioning left kidney. This was removed in 1950 and was found to be the seat of a calculous pyonephrosis.

Examination.-Spleen palpable. Limitation of movement of neck, shoulders, hips, wrists, all hand joints, knees, ankles, and mid-tarsal joints. Thickening and effusions present, and axillary lymph glands enlarged.

Laboratory Findings.-Blood pressure 120/60. X-rays showed subchondral erosions of bone. Erythrocyte sedimentation rate $100 \mathrm{~mm}$./hr (Westergren). Haemoglobin $9.6 \mathrm{~g}$. per cent. White blood count 5,600 per c.mm. (70 per cent. polymorphs). Colloidal gold 5. D.A.T. $1: 64$. Urine normal.

Two cutaneous and 27 subcutaneous nodules were seen on the hands and elbows, which histologically were typical of rheumatoid arthritis. She was improved by 6 weeks of ACTH gel and remained functionally fit and well on salicylates until 2 years later, although nodules still appeared on the tips of her fingers and were troublesome for housework.

She was re-admitted in 1952 and treated with ACTH and ACTH gel for one month with improvement, but also with the appearance of L.E.-like cells in the buffy coat and of urticaria.

Her third admission (October 1953) was due to wasting, anorexia, nausea, and the appearance of albuminuria. She was found to have hyperchloraemic acidosis of renal origin (blood urea $50 \mathrm{mg}$. per cent.). Pathological rib fractures were present. The urine was sterile and no calcification was seen on $x$-ray of the abdomen. The acidosis and weight loss were corrected by continued bicarbonate $4 \mathrm{~g}$. per day, cortisone $37.5 \mathrm{mg}$. per day, and a course of methyltestosterone, on which she greatly improved.

She has remained fit and well to the present without albuminuria, but the maximum specific gravity reached was 1,012. The cutaneous and subcutaneous nodules continually appeared and many were present at any one time. Two L.E. cells were found.

In addition to these nodules there appeared in February 1954 , one nail-edge lesion in the pigmented scar stage and one terminal pulp lesion in the early brown translucent stage. There were twelve of these intracutaneous nodules in the finger pads, mainly swollen white indurated papules (Fig. 22).

At a later stage they became pigmented scabs, seen in the index finger and thumb at the free margin of the nail and in the pulp of the index fingers. Biopsy of such a healing lesion showed hyperkeratosis and pigment in the desquamating horny layer (Fig. 23, opposite).

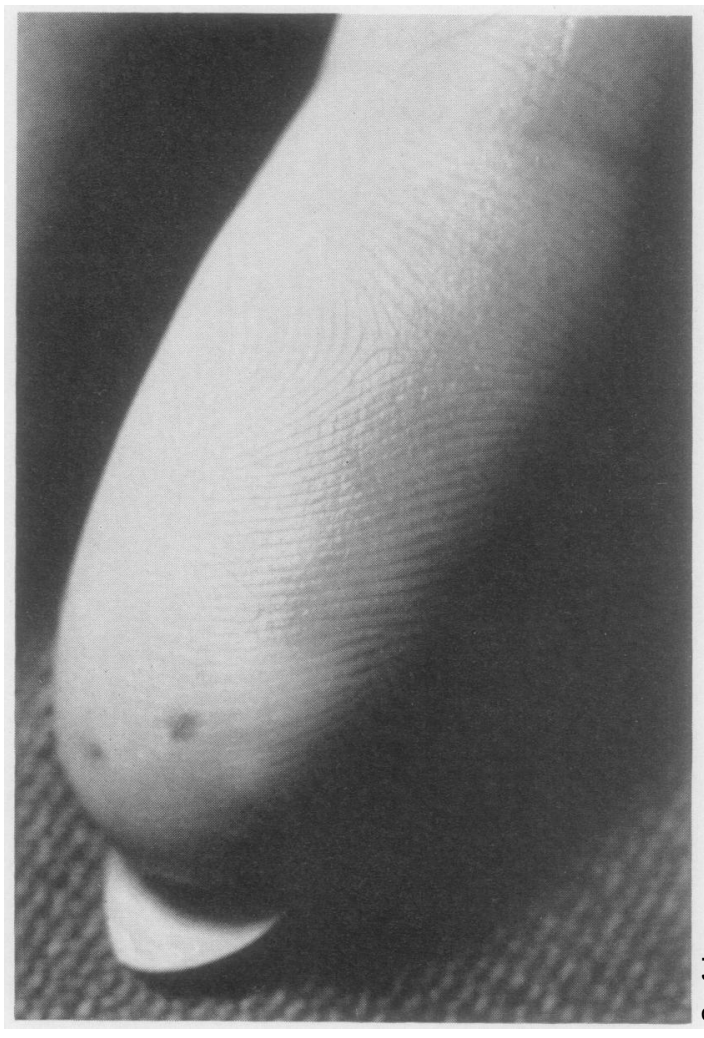

Fig. 22.-Case 3, left index finger, showing pulp papules and brown scars.

Laboratory Findings.-L.E. cells were looked for on sixteen occasions; on five occasions inclusion bodies were found, which were reported as L.E. cells but with traces of nuclear structure-probably to be classified as nucleophagocytosis (Fig. 24, opposite).

D.A.T. 1:128. No cryoglobulin or cold agglutinins were seen.

In October, 1956, she was well and fit, apart from rheumatoid arthritis, pulp and nail-fold lesions. The urine was normal and sterile, no L.E. cells found, blood urea normal, blood pressure 130/80.

The hyperchloraemic acidosis was probably due to pyelonephritis, but it seems possible that vascular lesions of the kidney of the type previously described might have brought this condition about. Thus Snapper, Seely, Falk, and Feder (1954) described a renal tubular lesion leading to osteomalacia as a result of scleroderma. Kincaid-Smith (1955) ascribed the renal scars of chronic pyelonephritis primarily 


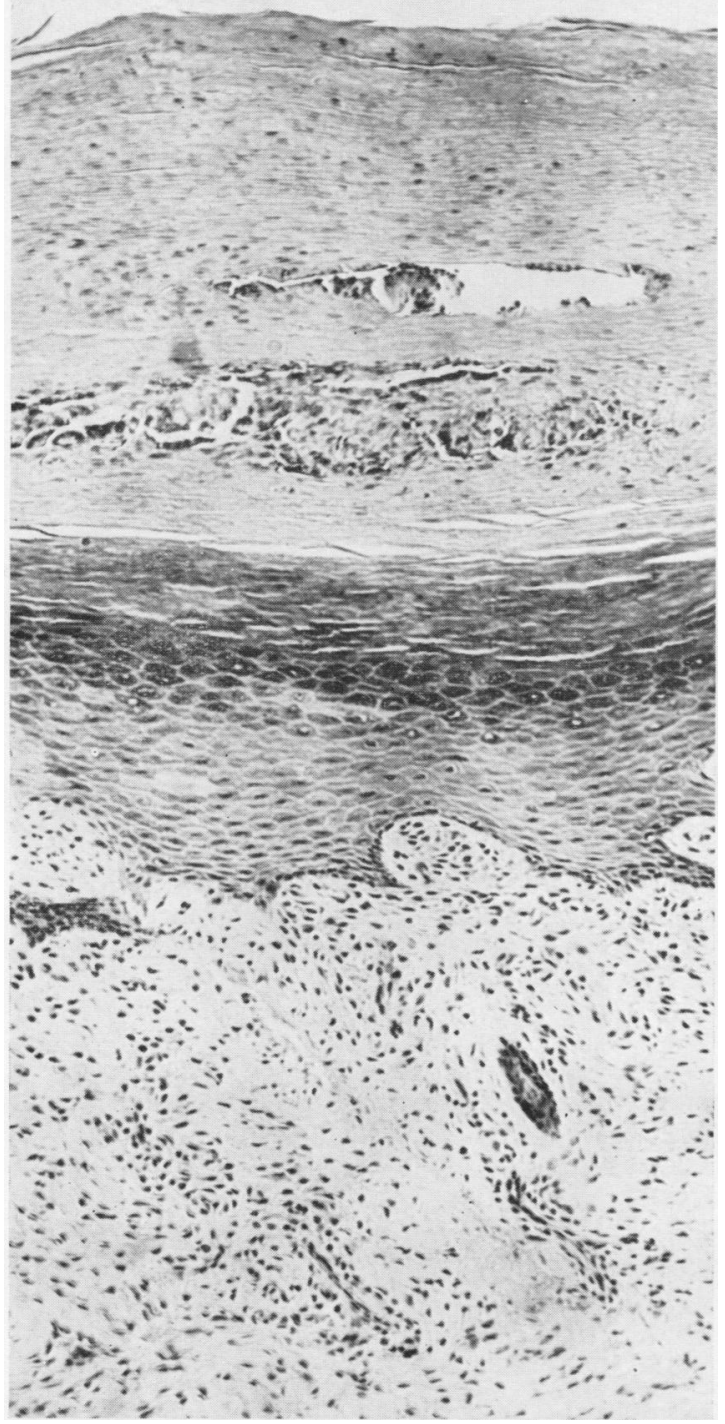

Fig. 23.-Case 3, section through brown scar, showing obliterative fibrosis and keratinization with desquamation. $H$ and $E . \times 40$.

to vascular lesions produced in the acute stage and characterized largely by intimal obliteration. However in Case 3 (above), a review of the small atrophic kidney removed surgically showed no intimal proliferation or other arterial lesion but changes compatible with chronic pyelonephritis.

Case 4, a male aged 48, was first seen at the Hammersmith Hospital in August, 1952, with a history of recurrent attacks of pain and stiffness lasting 12 to 24 hours since February, 1952.

In all, there had been about forty or fifty attacks in a

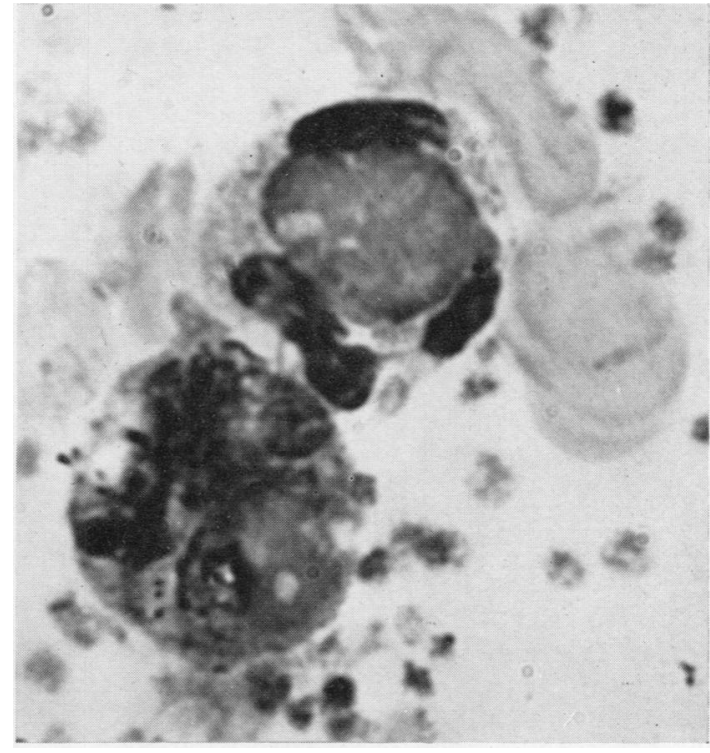

Fig. 24.-Case 3, Tart cell, originally reported as an L.E. cell. Leishman. $\times 2,000$.

period of 8 months, affecting the shoulders, wrists, hands, and left elbow. He was absolutely incapacitated during the attack but completely free of symptoms between; some swelling and heat occurred during the attacks. Examination showed no joint lesions, the erythrocyte sedimentation rate was $20 \mathrm{~mm}$./hr (Westergren).

He was admitted to the Canadian Red Cross Memorial Hospital in October, 1952, with swelling of the right index finger.

Laboratory Findings.-Erythrocyte sedimentation rate $42 \mathrm{~mm}$./hr (Wintrobe). White blood count 8,900 (68 per cent. polymorphs). D.A.T. 1:16. Colloidal gold negative. No L.E. cells seen.

The finger became normal next day after intravenous ACTH drip, but attacks continued throughout October and November.

Cortisone was started on November 19, 1952, and no attacks of any sort occurred in the following week, although in the week preceding cortisone therapy, three separate attacks had occurred, affecting the right knee, the hands, and the face. The next attack on December 6 (maintenance dosage cortisone $100 \mathrm{mg}$./day) was mild.

During a later reduction of cortisone dosage further attacks occurred and the erythrocyte sedimentation rate rose to $40 \mathrm{~mm}$. $/ \mathrm{hr}$.

When he was put on salicylates for one week, stiffness returned and pethidine was required.

He was therefore put back on to cortisone with some benefit, and was maintained on $87.5 \mathrm{mg}$./day together with acetyl-salicylic acid 4 to $5 \mathrm{~g}$./day. The erythrocyte sedimentation rate at this time was $23 \mathrm{~mm}$./hr.

By August, 1954, he was still having attacks but now with residual changes, typical of rheumatoid arthritis. The differential agglutination test was 1:32. There was some tingling of the fingers, and intra-cutaneous nodules 
had developed in his hands by November, 1954, especially in the neighbourhood of the nail-fold with brown papules becoming depressed (Fig. 25).

There were large subcutaneous nodules on the elbows, and "paronychia" on the right thumb, which had blistered and become secondarily infected, with lymphangeitis. This healed after incision, aureomycin, and splintage. The arthritis progressed on this regime, but no further vascular lesions have been seen up to November, 1956, although radiological joint erosions have now developed. No cryoglobulin or L.E. cells have been found.

Paronychia in patients with rheumatoid arthritis should be carefully evaluated, since there may be an ischaemic element besides infection. Prompt and continued antibiotic treatment is needed (see also Cases 1 and 8).

Case 5, a man aged 69, was admitted by Dr. P. H. Willcox to the Canadian Red Cross Memorial Hospital. He had had pain in the right wrist 14 months before, which spread to shoulders and elbows; it had been treated with phenylbutazone, short-wave diathermy, tooth-extraction, and gold. The patient had had typhoid at 13 years of age.

Examination on January 12, 1955, showed limitation of movement of the elbows, right knee, and cervical spine, and marked involvement of the joints of the hands; varicose veins characteristic of rheumatoid arthritis were seen on the palmar surface of the fingers.

There were sub-cutaneous nodules over both elbows, one of which was ulcerated. The right elbow showed in addition a ringed red papule resembling granuloma annulare about $0.7 \mathrm{~cm}$. across. There were two intracutaneous nodules in the terminal pad of the right thumb and one on the terminal interphalangeal flexor surface of the right index. On the left hand there were deep indurated lumps in the left thumb pad about $3 \mathrm{~mm}$. across one in the terminal pad on the left index, one on the ring finger, and one on the fifth finger. Red desquamating papules with superficial scars were seen at the second, third, and fourth interphalangeal joints. Lesions were also present at the free margins of the nails and in the nail beds (Fig. 26).

The former were brown patches, and the latter thromboses of the capillary loops (confirmed by microscopic examination).

Laboratory Findings.-Congo red test, 52 per cent. clearance in $30 \mathrm{~min}$. and 78 per cent. in $60 \mathrm{~min}$. Plasma protein $5 \cdot 1 \mathrm{~g}$. per cent., globulins $2 \mathrm{~g}$. per cent. Erythrocyte sedimentation rate $39 \mathrm{~mm}$. $/ \mathrm{hr}$ (Wintrobe). Haematocrit: 39 per cent., haemoglobin $10.7 \mathrm{~g}$. per cent White blood count 15,000 per c.mm. (polymorphs 82 per cent.). Urine no albumen. D.A.T. 1:64. No L.E. cells seen.

$X$-rays showed numerous erosions in the small joints of the hands and feet, and probable bronchiectasis at the right lung base.

Biopsy from the left elbow showed a characteristic rheumatoid nodule with central necrosis and palisading, and from the right index finger an area of diffuse inflammatory change and necrosis with an artery showing obliterative endarteritis (Fig. $27 a, b$, opposite).

A follow-up examination 10 months later showed little change except for healing of the finger lesions.

It is difficult to say from nail-fold microscopyo whether vascular thrombosis is a primary event of whether this follows changes in the extravascular connective tissue.

Case 6, a female aged 59, had a history of onset of rheumatoid arthritis in 1949, when she was aged 53, affecting numerous joints symmetrically, including hands and feet, with erosions visible radiologically; this had been treated with gold injections.

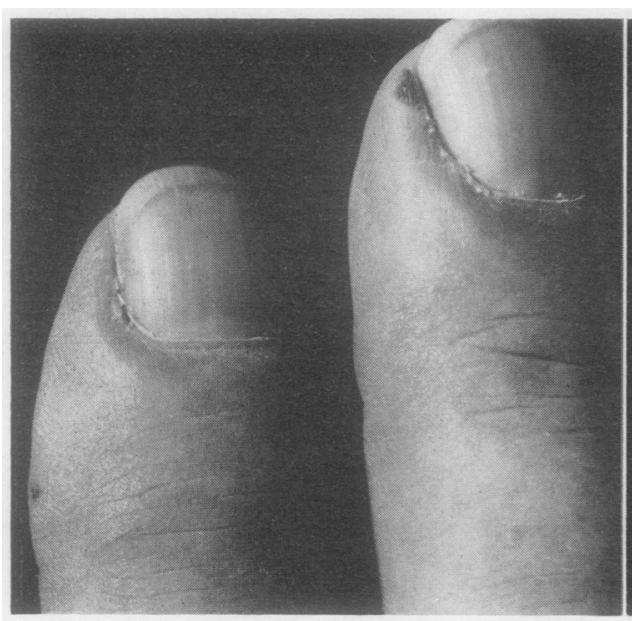

Fig. 25.-Case 4, brown scars in pulp of index and nailedge of third finger.

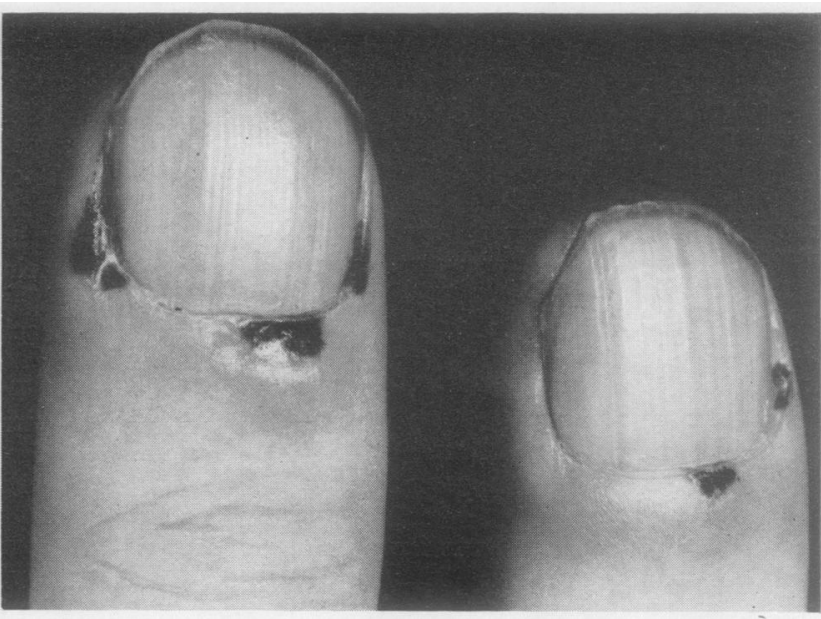

Fig. 26.-Case 5, fingers, showing nail-fold and nail-edge lesions. 


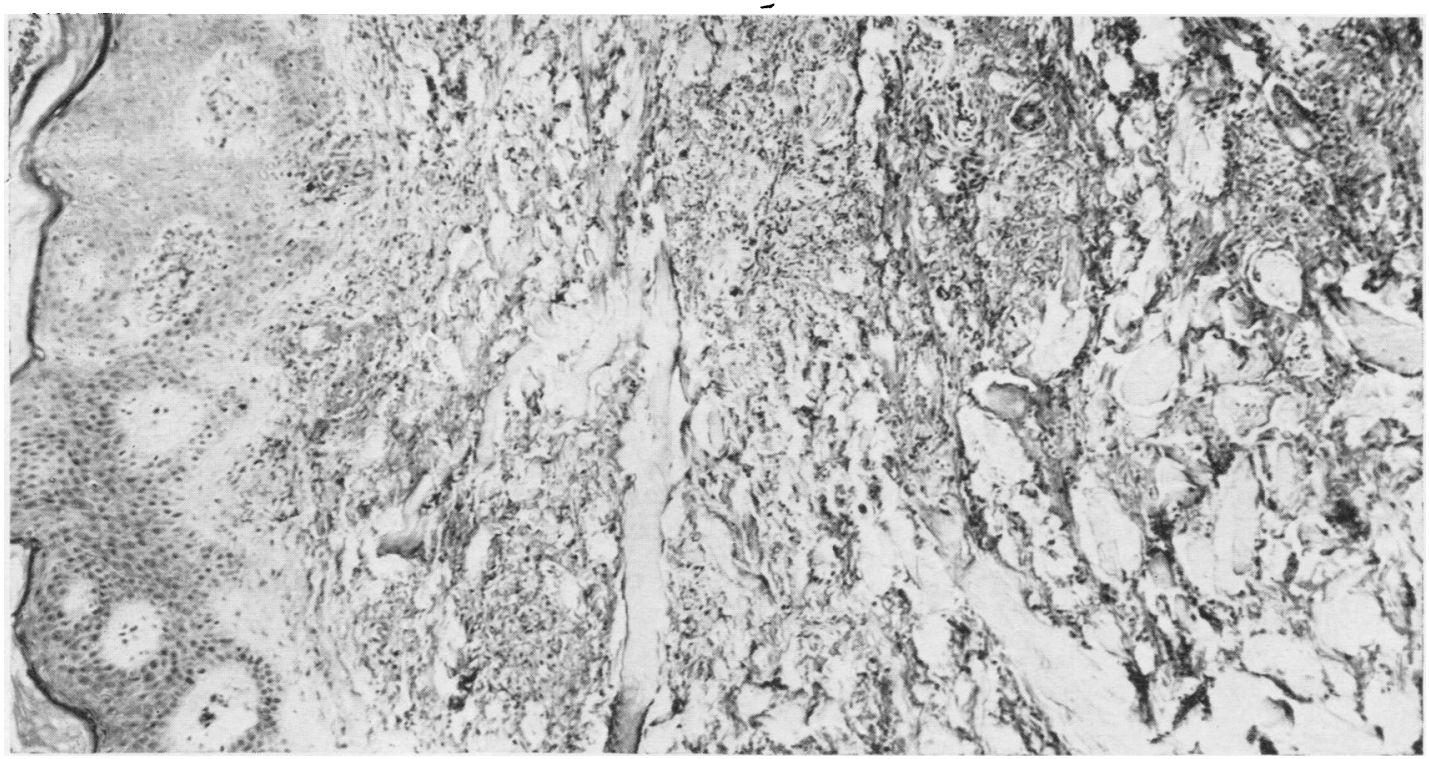

Fig. 27(a).-Case 5, section through nail-edge lesion, showing necrosis. $\mathrm{H}$ and $\mathrm{E} . \quad \times 80$.

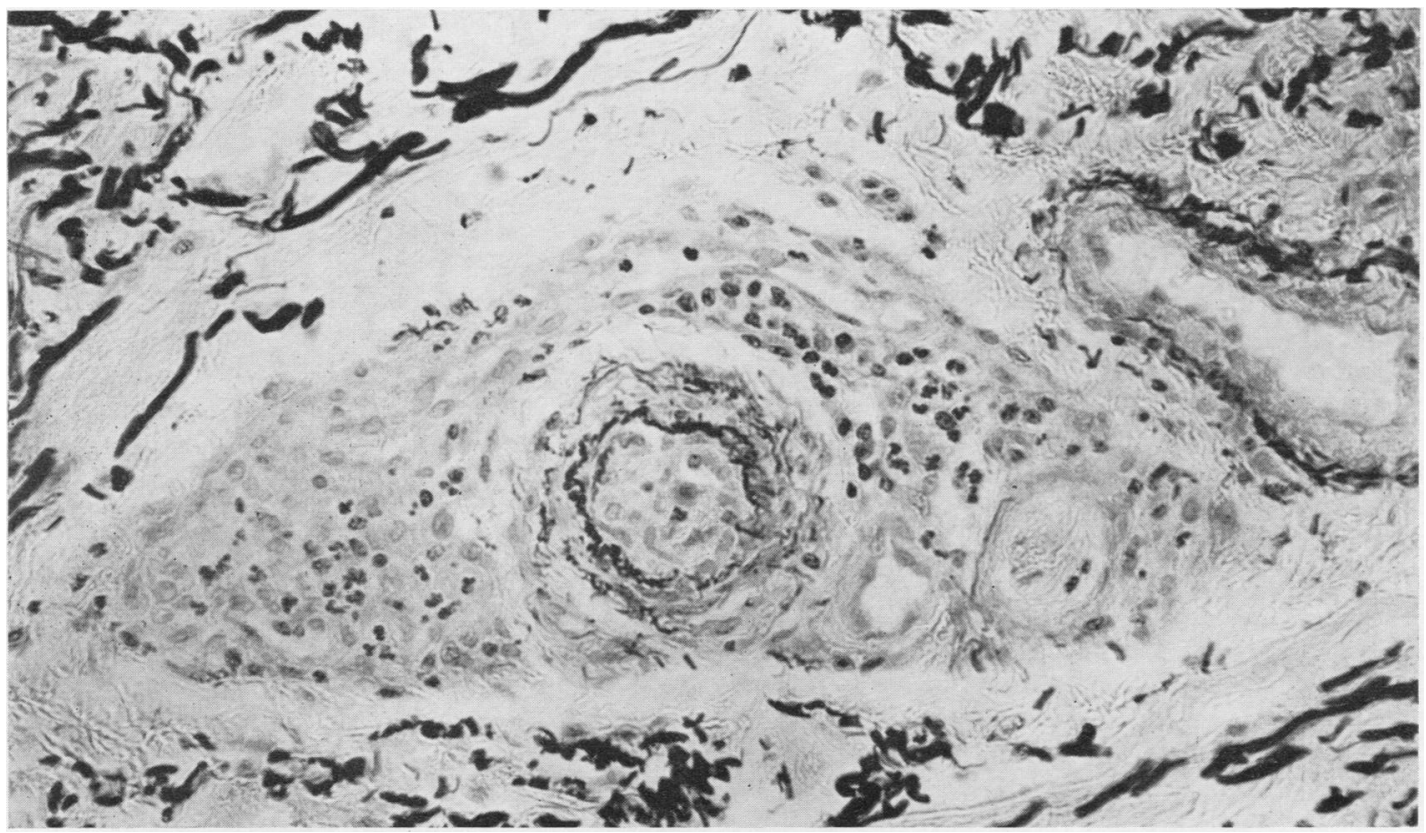

Fig. 27(b). - Case 5, obliterated artery from Fig. 27(a). Elastin. $\times 300$.

Sjögren's syndrome developed in 1951, and this was treated in 1955 with cortisone without much relief. She had then had subcutaneous nodules for some time. Within 2 weeks of starting cortisone therapy small intracutaneous nodules appeared on the hands. They persisted for 2 months with nail-base and nail-edge lesions in the forefinger and thumb and pulp nodules in the thumb, leading ultimately to pulp atrophy. The left elbow showed cutaneous and subcutaneous nodules. On a dosage of $100 \mathrm{mg}$. cortisone she ruptured the short extensor tendon of the third finger; this was repaired in May, 1955. Paraesthesiae and weakness of the left hand due to carpal tunnel compression were treated surgically by Mr. G. P. Arden in September, 1955, with slight improvement. 
Laboratory Findings.-Erythrocyte sedimentation rate $57 \mathrm{~mm} . / \mathrm{hr}$ (Westergren) before cortisone; differential agglutination test $1: 32$; white cell count normal; colloidal gold 3 ; urine normal; L.E. cell factor absent; cryoglobulin not present; Wassermann reaction and Kahn test negative.

The relation of the vascular lesions in the fingers to cortisone therapy seen in this patient and in Cases 2, 4, and 10, was close in point of time, but cannot be more than a contributory factor.

Case 7, a man aged 59, had a history of onset of rheumatoid arthritis in 1943, when he was aged 46.

In 1948 many joints were severely affected with erosions visible radiologically; nodules present; albuminuria; normal blood urea; erythrocyte sedimentation rate $68 \mathrm{~mm}$./hr (Westergren).

In 1952 he had haematuria but good renal function, pyelography normal, blood urea $40 \mathrm{mg}$. per cent.

In 1955, he was bed-fast, with albuminuria, pyelonephritis, and bed sores. Nail-fold and nail-edge lesions appeared.

Laboratory Findings.-Congo red test negative; differential agglutination test 1:256; white blood count 3,000 ( 72 per cent. polymorphs); Coombs test negative; cryoglobulin and L.E. cells not found.

$\mathrm{He}$ developed a toxic psychosis and was sent to a mental hospital (June, 1956) where he died (November, 1956) of pneumonia. Permission for autopsy was refused.

Case 8, a female aged 41, had a history of rheumatoid arthritis for 13 years. 18 months ago she developed red spots on the fingertips which were painful, became white, and then ulcerated. These healed 6 months later after treatment for one week with cortisone. However, pulmonary tuberculosis, for which she had been successfully treated 6 years previously, flared up, necessitating discontinuance of steroids in favour of chemotherapy.

Examination.-Quiescent pulmonary tuberculosis and old long-standing rheumatoid arthritis with subcutaneous nodules of the elbows. The pulp of the fingertips was scarred and atrophic (Fig. 28). No terminal phalangeal absorption was seen radiologically but joint erosions were present. Reactive hyperaemia showed loss of flushing and cyanosis of the fourth finger of the left hand, unless the hand was warmed beforehand. This finger went cold and blue in winter.

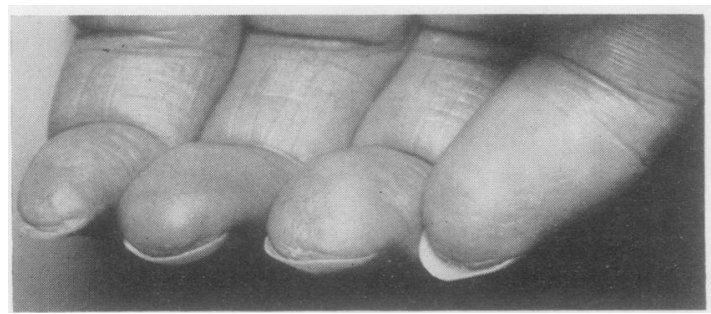

Fig. 28.-Case 8, pulp of fingers, showing atrophic scarring.

Laboratory Findings.-D.A.T. 1:16; no L.E. cells found; no cold agglutinins or cryoglobulin detected; Wasserman reaction and Kahn test negative; erythrocyte sedimentation rate $41 \mathrm{~mm}$./hr (Wintrobe).
Case 9, a female aged 31, was seen at the West Middlesex Hospital on July 9, 1954, under the care of Dr. R. P. K. Coe.

She had a history of recurrent attacks of what was diagnosed as rheumatic fever in 1946 and 1949, and attacks of rheumatoid arthritis in 1951 and again in $1953 \overrightarrow{\bar{F}}$ lasting until the present time. She had been treated with Myocrysin and Butazolidin, reacting to the latter with a rash. An exacerbation has occurred recently with $\frac{\bar{\sigma}}{\bar{D}}$ diplopia, episcleritis, and gross swelling of the wrists, $\frac{\mathcal{S}}{\partial}$ first on the right side and then on the left, with tenosynovitis and development of nodules.

Examination.-No iritis. No loss of hair. On the $\vec{\circ}$ left elbow there are cutaneous and subcutaneous nodules: the former contain a central brown fleck. She has had $\vec{\omega}$ nodules in the pulp of the fingers, but none are present at the moment.

The wrists are limited in extension as are the fingers. ? There is gross tenosynovitis with nodules in the palmar $\vec{\sigma}$ spaces over the tendons. High fever is not controlled by $\vec{\phi}$ aspirin, despite which she has felt fit enough to carry on school-teaching throughout.

Laboratory Findings.--Erythrocyte sedimentation rate $120 \mathrm{~mm} . / \mathrm{hr}$ (Westergren); D.A.T. $1: 8$; L.E. cells found in peripheral blood and marrow; skin nodule (biopsied) shows areas of fibrinoid necrosis and basophilic nuclear $\frac{\rho}{\square}$ fragments together with necrotizing arteritis (Fig. 29, $\vec{\theta}$ opposite); $x$-rays of hands (July, 1954) no abnormality: $\mathcal{G}$ white blood count showed leucopenia on one occasion. 0

This histological picture is very similar to that seen Case 5 .

Case 10, a female aged 42, had a history of rheumatoid arthritis for 4 years since 1952. She had had ACTH, 용 gold, Butazolidin, and more recently aspirin.

Examination.-Severe involvement of many joints with deformity, all peripheral pulses present, subcutaneous and cutaneous nodules right elbow, pulp nodule right thumb due to winding watch, nail-fold thromboses and nail-edge lesions which have been present for some time.

Laboratory Findings.-Reactive hyperaemia test nor-을 mal; capillary microscopy of nail-folds shows haemor rhagic areas and some thrombosed vessels; differentiali agglutination test $1: 128$; no L.E. cells found, but $\frac{\text { O }}{3}$ nucleophagocytosis marked; erythrocyte sedimentation rate $70 \mathrm{~mm} . / \mathrm{hr}$ (Westergren); Wassermann reaction negative; direct Coombs test negative: no albuminuria.

Bone erosions seen radiologically; white cell counto 4,000 (44 per cent. polymorphs); cryoglobulin not” present.

Her condition deteriorated so that she could no longern use her hands and no further nodules had appeared. SheN was re-admitted 4 months later with laryngeal stridor $\omega$ simulating bilateral abductor palsy but later shown to be due to cricoarytenoid arthritis responding dramaticallye to prednisone. After 2 weeks, nail-fold thromboses returned in numerous fingers and at the same time pulp? and nail-edge lesions appeared together with intra- 7 cutaneous nodules on the elbows. No cryoglobulins orō

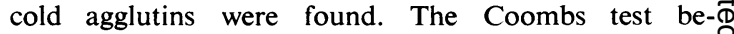




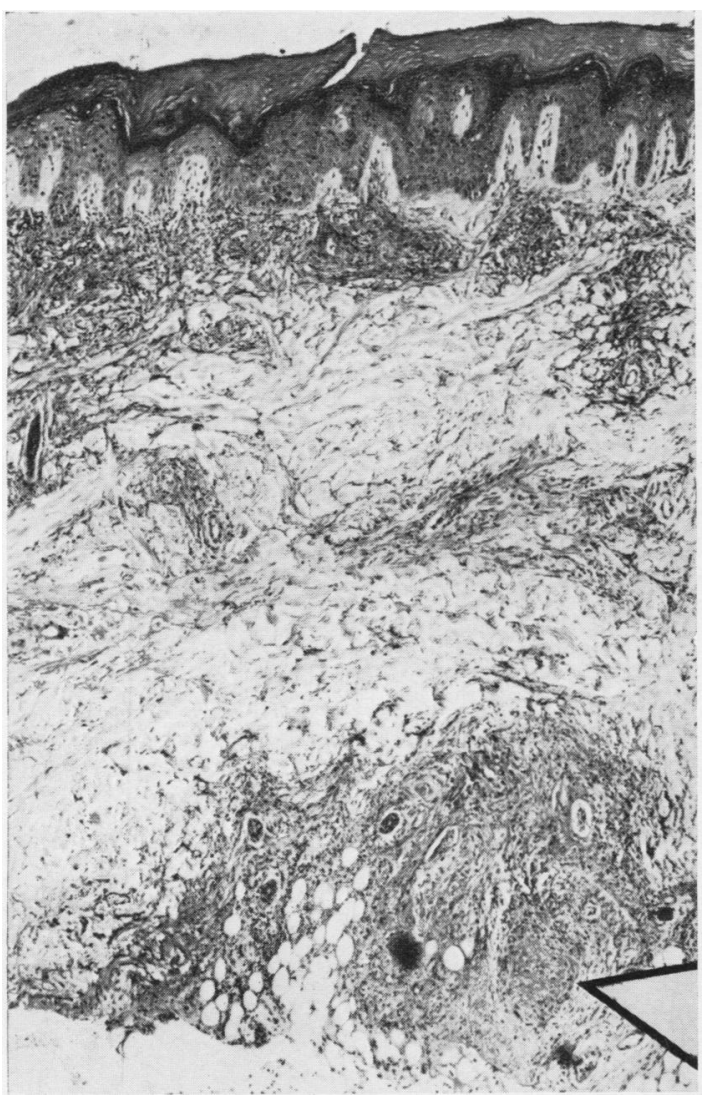

Fig. 29.-Case 9, necrosis in digital pulp nodule and obliterated artery in the base of this (Arrow). $\mathrm{H}$ and $\mathrm{E} . \quad \times 35$.

came temporarily positive, and L.E. cells appeared (by a defibrination method) in the buffy coat. These were fairly numerous, and beyond doubt. Some nucleophagocytosis was also seen. Biopsy of a cutaneous nodule showed acute necrosis similar to that depicted in Figs $27 a$ and 29.

This appears to be the type of malignant rheumatoid arthritis which occasionally shows the L.E. cell phenomenon. We have not found it present, however, in the large proportion of cases (12-15 per cent.) recorded by Kievitz, Goslings, Schuit, and Hijmans (1956).

\section{Discussion}

Types of Arterial Involvement in Rheumatoid Arthritis.-Clinically evident involvement of blood vessels in rheumatoid arthritis is comparatively rare although, as Cruickshank (1954) has pointed out, minor pathological changes in the smaller vessels of the heart, voluntary muscles, and nerve sheaths may be found on detailed post-mortem study in 25 per cent. of hospitalized rheumatoid arthritis patients.
Some of these have rheumatic heart disease and the changes are localized chiefly in the heart, being probably rheumatic in origin, and some have no rheumatic heart disease and the changes are more widely distributed and show somewhat more destruction. Cruickshank found no correlation with the clinical state. Such changes have also been seen near granulomatous areas, including the subcutaneous nodule of rheumatoid arthritis (Collins, 1937; Sokoloff, Wilens, and Bunim, 1951 ; Sokoloff, McCluskey, and Bunim, 1953).

Occasionally a more severe type of arteritis is seen in rheumatoid arthritis, of a severity and distribution that cannot be distinguished from clinical polyarteritis nodosa (Ball, 1954; Graef, Hickey, and Altman, 1949; Ogryzlo, 1953; Nyström, 1953).

The type of arteritis described in our ten patients with rheumatoid arthritis seems, however, to be different from both the above types. The distribution of lesions in the two cases coming to post mortem examination is similar to that seen in generalized visceral polyarteritis nodosa, but the morphological character of the lesion is generally quite distinct, being a bland intimal proliferation of fibroblasts and mucoid material, sometimes with secondary fibrin clots on it (similar in many ways to the changes characteristic of scleroderma, described originally by Masugi and Yä (1938), of which we have seen several classical examples). The internal elastica appears to suffer secondarily as it does also beneath atheromatous plaques; there is rarely evidence of an old adventitial reaction with haemosiderin and only in the coronary artery of Case 2 was there considerable panarteritis. In Case 1 three types of vessel changes are to be distinguished:

(1) a primary intimal obliteration;

(2) an elastica duplication and intimal thickening in unaffected arteries due to hypertension;

(3) the terminal necrotic lesions of the malignant phase.

In those cases with only passing involvement, the clinical signs were closely similar to those appearing in the two fatal cases, i.e. nail-fold, nail-edge, finger pulp, and other cutaneous digital lesions, ending up as a brown keratinizing spot with little residual tissue loss; these were fully described and illustrated in the first publication (Bywaters, 1949). The three biopsies available showed intimal obliteration and territorial infarction without other change in two cases (Cases 5 and 9), and the healed desquamating stage in the third case (Case 3 ). It is thought, therefore, that the basic pathological change in all these ten cases is of the same nature.

Is it specific for rheumatoid arthritis? Probably not. While it appears distinct from Buerger's 
disease, in the absence of gross vessel-wall change and venous involvement, and from polyarteritis nodosa and temporal arteritis, some cases have been recorded which appear to correspond closely; these are well summarized by Whiteley and Wilson (1952), who record one case and cite seven other possible ones from the literature. Since then Edwards (1956) has written concerning a remittant necrotizing acrocyanosis with intimal proliferation; in one, at least, of his twelve patients, rheumatoid arthritis occurred (Friend and Edwards, 1954), and showed nail-edge lesions (illustrated) similar to those recorded here. Lewis and Pickering (1934) also recorded a woman (Case 19) with metacarpophalangeal swelling and ulnar deviation who developed digital gangrene with intimal thickening proximal to the necrotic parts. More recently, Taubenhaus, Eisenstein, and Pick (1955) have recorded a similar case of a patient with rheumatoid arthritis for 15 years who developed gangrene of the finger-tips due to a proliferative endarteritis; this patient, however, had had cortisone for 4 years. Others have also recorded arteritis in patients treated with cortisone (Finck, 1955; Levin, Rivo, Scott, Figueroa, Fred, and Barrett, 1953; West and Newns, 1953; Robinson, French, and Duff, 1953; Etheridge and Hoch-Ligeti, 1952; Weinberger, 1953), but in most of these the angiitis was of the polyarteritis nodosa type. In our own series, Case 1 was seen in the pre-cortisone era, and three only of the remaining nine had received cortisone before the development of the vascular symptoms. While, therefore, some suspicion attaches to steroid therapy, particularly in some cases where there was a close relationship in time between therapy and symptoms, and while also there is evidence that necrotizing lesions occur in the aorta of hamsters treated with cortisone (Steffee and Snell, 1955), it seems more likely to the present author that these lesions are part and parcel of the rheumatoid syndrome and that their association with cortisone therapy is a secondary one.

Relationship to Vascular Changes in Lupus Erythematosus and Other Conditions.- These changes described in rheumatoid arthritis resemble somewhat the obliterative mucoid endarteritis of scleroderma, which brings about the explosive renal failure characteristic of that condition. In general they are less "mucoid" and, although we have seen fibrinoid in the arterial wall of two cases of scleroderma, the latter condition (and this is true also for Henoch's purpura) seldom shows such acute changes unless there is severe terminal hypertension.

However, in lupus erythematosus (Bywaters, 1956), we have seen a very similar type of intimal proliferation associated with gangrene of the limbs, or, short of this, with large necroses and ulcerations of गु thumbs, fingers, legs, and scapular and triceps areas, in minor degree producing transient cyanosis of one 3 finger over several months, or at least small nail- $\frac{D}{\omega}$ edge and digital-pulp lesions. If the tempo is slow, cicatrization will occur without obvious necrosis; we have seen this in the kidney and also in the finger $\overrightarrow{0}$ leading to absorption of the terminal pulp.

The minor acute lesions of the digital pulp in acute $\overline{\bar{c}}$ lupus erythematosus are well known; in a series of $\mathbb{\nabla}$ 57 patients investigated in Boston (Bauer and Bywaters, unpublished data), such lesions were seen in fifteen patients, and we have seen them since also in chronic disseminated discoid lupus erythematosus $\overrightarrow{\vec{\omega}}$ with occasional "visceralization". The more severe lesion leading to bone absorption (Omens and Tobin, 1940; Luniatschek and Kettner, 1939) or ulcers? (Dziobek and Cseh, 1939) is rarer, and gangrene is $\vec{\sigma}$ rarer still. The gamut of these rheumatoid changes, $\vec{\infty}$ however, is very similar to those detailed above for $\stackrel{\oplus}{\circ}$

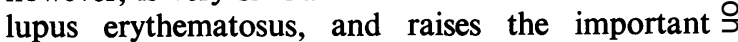
question whether the rheumatoid patients described really had rheumatoid arthritis or lupus erythematosus. Eight out of ten had a positive D.A.T., which might be given in both diseases. The L.E. cell phenomenon, however, was reported positive in $\mathcal{G}$ three and repeatedly negative in six.* Two showeg. nucleophagocytosis. In Case 1 the test was not done. The status of the positive tests in two cas is doubtful: one was done at another hospital and the other (Case 3) was done 3 years ago when the difference between tart cells and L.E. cells was $\varrho$ not adequately appreciated; a photograph of the $\overrightarrow{\vec{O}}$ best preparation shows what is obviously nucleo- $\frac{3}{3}$ phagocytosis and no L.E. cells have been seen since that time. However, whether the L.E. cello phenomena was present as in Case 10 or not, the course in all these patients was that of rheumatoid 0 arthritis, i.e. prolonged chronic deforming poly- $\frac{3}{3}$ arthritis, lasting 2 to 13 years, with joint erosion visible radiologically in nine out of ten patients, and $\mathrm{O}$ little else suggestive of lupus erythematosus except in

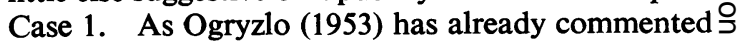
in a similar context, if a diagnosis is to have any meaning at all in a disease of unknown aetiology, it must indicate prognosis, and the prognosis of these $N$ patients is that of rheumatoid arthritis in the classical sense, not that of acute lupus erythematosus.

It is recognized, however, that the two diseases are $\omega$ similar in many respects, and that it is unwise and? unfruitful to devise nice distinctions, except for theo

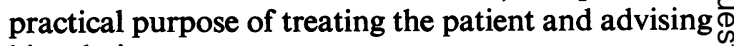
his relatives.

* L.E. cell formation was studied in smears of the buffy coat layer from clotted blood or blood taken into a Wintrobe-oxalated tube. 
Pathogenesis of Lesions.-Cryoglobulins, although recorded in rheumatoid arthritis (Feldaker, Perry, and Hanlon, 1956), have not been found in pathological amount in the seven cases investigated here (Table), nor have cold agglutinins. It might be that the occlusion is due to spasm, with secondary thrombosis and vessel obliteration spreading up from the digits, producing a secondary passive luminal closure as seen in various involuting organs, but it seems much more likely in view of the widespread limb and visceral changes that this is primarily a lesion of the vessel wall, perhaps similar to the proliferative process which produces subcutaneous nodules (present in all patients) or synovial membrane hyperplasia. The condition did not appear to be improved by cortisone.

\section{Summary}

Ten cases of rheumatoid arthritis have been described, which showed vessel obliteration associated with symptoms ranging from small infarcts, presenting as brown lesions of the nail-fold, nail-edge, or digital pulp, to gangrene of all four limbs with visceral lesions. This is not thought to represent polyarteritis nodosa or Buerger's disease, but to resemble more closely the arterial changes seen in scleroderma and lupus erythematosus, and perhaps also the changes described as "remittent necrotizing acrocyanosis" (Edwards, 1956) or "nonspecific obliterative angiitis" (Pennock and Primas, 1956). None showed the ordinary symptoms of Buerger's disease, although all except one were ambulant. It is not felt that cortisone played any important part, since only three of the ten had had such preceding treatment.

I am grateful to Dr. P. H. Willcox and Dr. R. P. K. Coe for allowing me to use data on Cases 10,5 , and 9 ; to Professor J. H. Dible for permission to use the data he provided by radio-opaque injection in Case 4, and to him, Professor R. V. Harrison, and Dr. L. E. Glynn for use of the pathological material and data.

\section{REFERENCES}

Ball, J. (1954). Annals of the Rheumatic Diseases, 13, 277.

Bauer, W., and Bywaters, E. G. L. (1956). Unpub. data.

Boulet, P., Serre, H., Vedel, A., Vallat, G., and Mirouze, J. (1949). Bull Soc. med. Hôp. Paris, 65, 47.

Bywaters, E. G. L. (1949). Annals of the Rheumatic Diseases, 8, 1. (Case 2)

- (1956). Unpub. data.

Chasnoff, J., and Vorzimer, J. J. (1944). Ann. intern. Med., 20, 327

Collins, D. H. (1937). J. Path. Bact., 45, 97

Collins, D. H. (1937). J. Path. Bact., 45, 97.

Cruickshank, B. (1954). Annals of the Rheumatic Diseases, 13, 136.

Dziobek, L., and Cseh, E. (1939). Dermatologica (Basel)

Etheridge, E. M., and Hoch-Ligeti, C. (1952). Amer. J. Path., 28, 315. Feldaker, M., Perry, H. O., and Hanlon, D. G. (1956). A.M.A. Arch. Derm., 73, 325.

Finck, P. A. (1955). A.M.A. Arch. Path., 60, 374.

Friend, D. G., and Edwards, E. A. (1954). A.M.A. Arch. intern. Friend, Med., 93, 928 .

Graef, I., Hickey, D. V., and Altman, V. (1949). Amer. Heart J., 37, 635 .

Hejtmancik, M. R., and Bruce, E. I. (1953). Ibid., 45, 289.
Kievits, J. H., Goslings, J., Schuit, H. R. E., and Hijmans, W. (1956). Annals of the Rheumatic Diseases, 15, 211.

Kincaid-Smith, P. (1955). Lancet, 2, 1263.

Levin, M. H., Rivo, J. B., Scott, W., Figueroa, W. G., Fred, L., and Barrett, T. F. (1953). Amer. J. Med., 14, 265

Lewis, T., and Pickering, G. W. (1934). Clin. Sci., 1, 327.

Luniatschek, V., and Kettner, H. U. (1939). Med. Klin., 35, 216.

Masugi, M., and Yä, S. (1938). Virchows Arch. path. path. Anat. 302, 39.

Myerson, R. M., and Stout, R. E. (1955). Amer. J. med. Sci., 230, 499.

Nyström, G. (1953). Ann. Med. intern. Fenn., 42, 52.

Ogryzlo, M. A. (1953). Annals of the Rheumatic Diseases, 12, 323. Omens, D. V., and Tobin, W. W. (1940). Arch. Derm. Syph. (Chicago), 41, 1162.

Pennock, L. L., and Primas, H. D. (1956). Angiology, 7. 32.

Robinson, W. D., French, A. J., and Duff, I. F. (1953). Annals of

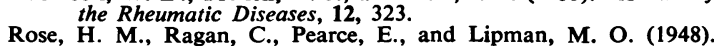
Proc. Soc. exp. Biol. (N.Y.), 68, 1 .

Sokoloff, L., McCluskey, R. T., and Bunim, J. J. (1953). A.M.A. Arch.'Path., 55, 475.

-., Wilens, S. L., and Bunim, J. J. (1951). Amer. J. Path., 27, 157.

Snapper, I., Seely, R., Falk, S., and Feder, I. (1954). Ann. intern. Med., 41, 893.

Stammers, F. A. R. (1954). J. Bone Jt Surg., 36B, 209.

Stats, D., and Bullowa, J. G. W. (1943). Arch. intern. Med., 72, 506. Steffee, C. H., and Snell, K. C. (1955). Proc. Soc. exp. Biol. (N.Y.), 90,712 .

Swan, W. G. A., and Henderson, C. B. (1951). Brit. Heart J., 13, 68. Taubenhaus, M., Eisenstein, B., and Pick, A. (1955). Circulation, 12, 903 .

Taylor, A. W., and Jacoby, N. M. (1949). Lancet, $2,792$.

Weinberger, H. J. (1953). Annals of the Rheumatic Diseases, 12, 324. West, H. F., and Newns, G. R. (1953). Lancet, 2, 1123.

Whiteley, H. J., and Wilson, G. M. (1952). J. Path. Bact., 64, 705.

Obstruction vasculaire périphérique dans l'arthrite rhumatismale et ses relations avec les autres lésions vasculaires

RÉSUMÉ

On décrit dix cas d'arthrite rhumatismale présentant des oblitérations artérielles associées à une série de lésions, allant de petits infarctus caractérisés par des lésions brunes du pli de l'ongle, du bord de l'ongle ou de la pulpe digitale jusqu'à le gangrène des quatre membres et aux lésions viscérales. On ne croit pas que cela représente la polyartérite noueuse ou la maladie de Burger, mais plutôt les altérations artérielles rencontrées dans la sclérodermie et le lupus érythémateux, et peut-être aussi, celles décrites comme "acrocyanose nécrotisante rémittente" (Edwards, 1956) ou "angéite oblitérante nonspécifique" (Pennock et Primas, 1956). Aucun des malades ne présentait les symptômes ordinaires de la maladie de Bürger, bien que tous, sauf un, marchassent. On ne pense pas que la cortisone ait joué un rôle car seuls trois des dix malades avaient été traités avec ce produit.

Obstrucción vascular periférica en la artritis reumatoide y sus relaciones con otras lesiones vasculares Sumario

Se describen diez casos de artritis reumatoide presentando obliteraciones arteriales asociadas con una serie de lesiones, yendo de pequeños infartos caracterizados por lesiones pardas del pliego de las uñas, del borde de las uñas o de la pulpa digital hasta la gangrena de los cuatro extremidades y las lesiones viscerales. No se cree que se trate aquí de la poliarteritis nodosa o de la enfermedad de Buerger, sino más bien de alteraciones arteriales encontradas en la esclerodermia y en el lupus eritematoso y, quizás, de alteraciones descritas como "acrocianosis necrotisante remitente" (Edwards, 1956) o "angeitis obliterante non-específica" (Pennock y Primas, 1956). Ninguno de los enfermos presentó síntomas ordinarios de la enfermedad de Buerger, aunque todos salvo uno andasen. No se cree que la cortisona hubiese desempeñado papel alguno, ya que tan solo tres de los diez enfermos habian recibido este producto. 